\title{
Diversidade de Bactérias do Sedimento de Manguezal da Ilha do Cardoso Cananéia - São Paulo
}

Armando Cavalcante Franco Dias

Dissertação apresentada ao Programa de PósGraduação Interunidades em Biotecnologia USP/Instituto Butantan/IPT, para obtenção do Título de Mestre em Biotecnologia.

São Paulo 


\section{Diversidade de Bactérias do Sedimento de Manguezal da Ilha do Cardoso Cananéia - São Paulo}

Armando Cavalcante Franco Dias

Dissertação apresentada ao Programa de PósGraduação Interunidades em Biotecnologia USP/Instituto Butantan/IPT, para obtenção do Título de Mestre em Biotecnologia.

Área de concentração: Biotecnologia

Orientador: Prof. Dr. Welington Luiz de Araújo

São Paulo 
DADOS DE CATALOGAÇÃO NA PUBLICAÇÃO (CIP)

Serviço de Biblioteca e Informação Biomédica do

Instituto de Ciências Biomédicas da Universidade de São Paulo

(C) reprodução total

Dias, Armando Cavalcante Franco.

Diversidade de Bactérias do sedimento de manguezal da lha do Cardoso Cananéia. - São Paulo / Armando Cavalcante Franco Dias. -São Paulo, 2007.

Orientador: Welington Luiz de Araújo.

Dissertação (Mestrado) - Universidade de São Paulo. Instituto de Ciências Biomédicas. Departamento de Biologia Celular e do Desenvolvimento. Área de concentração: Biotecnologia. Linha de pesquisa: Ecologia microbiana.

Versão do título para o inglês: Bacterial Diversity in sediment from mangrove of the island Cardoso Cananeia - Sao Paulo.

Descritores: 1. Ecologia microbiana 2. Análise mutivariada 3. DGGE 4. ARDRA 5. RDA 6. Enzimas I. Araújo. Welington Luiz II. Universidade de São Paulo. Instituto de Ciências Biomédicas. PosGraduação em Biotecnologia III. Título. 
Candidato(a): $\quad$ Armando Cavalcante Franco Dias.

Título da Dissertação: Diversidade de Bactérias do sedimento de manguezal da ilha do cardoso Cananéia - São Paulo .

Orientador(a): $\quad$ Welington Luiz de Araújo.

A Comissão Julgadora dos trabalhos de Defesa da Dissertação de Mestrado, em sessão pública realizada a ...................,

\section{( ) Aprovado(a) ( ) Reprovado(a)}

Examinador(a): Assinatura:

Nome:

Instituição:

Examinador(a): Assinatura:

Nome:

Instituição:

Presidente: $\quad$ Assinatura:

Nome:

Instituição: 


\section{CERTIFICADO DE ISENÇÃO}

Certificamos que o Protocolo CEP-ICB N ${ }^{\circ}$ 239/07, referente ao projeto intitulado: "Diversidade de bactérias do sedimento de manguezal da ilha do Cardoso - Cananéia- São Paulo“ sob a responsabilidade de Armando Cavalcante Franco Dias, foi analisado na presente data pela CEEA - COMISSÃO DE ÉTICA EM EXPERIMENTAÇÃO Animal e pela CEPSH - COMISSÃo de Ética EM PESQUisa COM SERES HUMANOS, tendo sido deliberado que o referido projeto não envolve manipulação animal ou humana que justifique uma aprovação quanto aos princípios éticos exigidos por ambas as Comissões.

São Paulo, 13 de novembro de 2007.

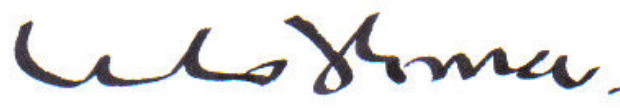

Prof. DR. WOTHAN TAVARES DE LIMA Coordenador da CEEA - ICB/USP

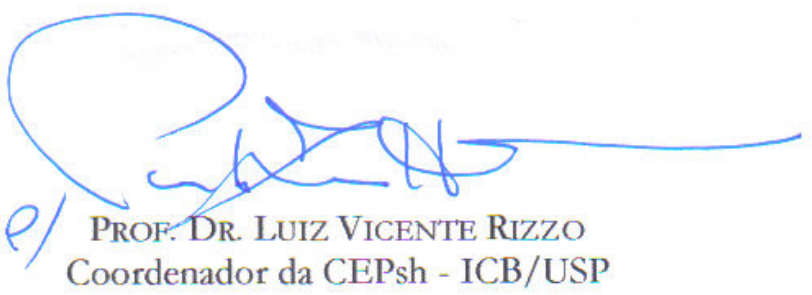


A minha mãe Solange Cavalcante, que em cada brisa no meu rosto sua presença me fortalece e a minha segunda mãe Tia Maria Franco por acreditar e incentivar em todos os momentos.

\section{DEDICO}

Ao meu pai Oraldo Dias, Aline Franco e Rafaela Franco e de maneira especial a Kelly pela força, incentivo e confiança. 


\section{AGRADECIMENTOS}

O programa de Pós-graduação Interunidades proporcionou um leque imenso de amizades e aprendizado, tanto científico como no amadurecimento pessoal. Agradecer a todas as pessoas que me ajudaram daria uma outra dissertação, mas enfim algumas foram indispensáveis para a elaboração da mesma. Deus e meus familiares foram a base de tudo.

Primeiramente ao meu orientador Prof. Dr. Welington Luiz de Araújo pela sua competência como pesquisador, amizade, descontração, cobrança, calma e muita paciência;

Agradeço também ao Prof. Dr. Itamar Soares de Melo pela confiança, incentivo, respeito e principalmente pela amizade;

De maneira especial ao meu mais que co-orientador e amigo Fernando Dini Andreote pelos ensinamentos empíricos, científicos, sentimentais e práticos. Valeu Moska!!!

Ao meu sócio e companheiro de pesquisa desde outras vidas André Luís Braghini Sá pelos momentos difíceis, alegres e pela sua sensatez, inteligência, honestidade e ombro amigo em todos os momentos;

Aos Profs. Msc. Francisco E. C. Costa e Dr. Manoel Araújo Teixeira por me fazerem enxergar o mundo da pesquisa.

A galera lá do CRUSP e de Sampa-Capital onde parte do meu aprendizado se fez e grandes amizades aconteceram em especial ao Dr. Ricardo Menghini e Profa. Dra Yara Schaffer Novelli por me mostrarem a beleza do ecossistema de manguezal;

Ao pessoal da Embrapa Meio Ambiente, João Luis, Rosely, Rosana Faria, todos os técnicos e estagiários e também a galera da república de Jaguariúna em especial ao meu amigo Alexandre Sereda que é mais que um irmão, sempre pronto e disposto a ajudar;

A todos os colegas de trabalho que fazem parte do laboratório de genética de microrganismos em especial a Profa. Dra. Aline Aparecida Pizzirani-Kleiner e ao Prof. Dr. João Lúcio de Azevedo pela maneira carinhosa que me acolheram e aos amigos e amigas: Aline S. Romão, Ana Paula Pallu, Anderson Ferreira, Andrea Bogas, Carlos Vildoso, Danice Luvizotto, 
Fernanda Sebastianes, Fernanda Bernardes, Francisco Andreote, Joelma Marcon, José Antonio da Silva (vulgo Zezo), Júlia Kuklinsky-Sobral, Laura Assumpção, Léia Fávaro, Manuella Dourado, Maria Beatriz Calderan, Maria Carolina Quecine, Marise Suzuki, Michele Silva, Paulo Lacava, Priscilla Rossetto, Renata Assis, Rodrigo Mendes, Rodrigo Stuart, Uira Belmonte, Vanessa Cicera;

A FAPESP/BIOTA e CNPq pela bolsa e financiamento para o desenvolvimento da dissertação.

\section{OBRIGADO A TODOS.}


" $O$ verdadeiro mestre se faz aprendiz para que seus seguidores aprendam com ele enquanto pensam que ensinam"

(David Cristofoletti) 


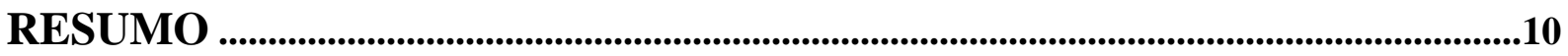

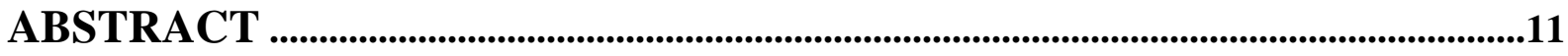

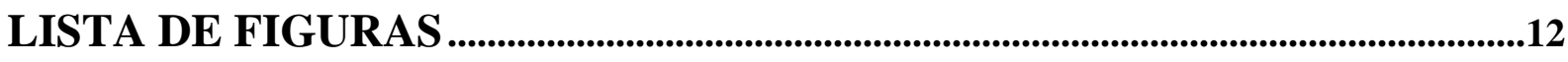

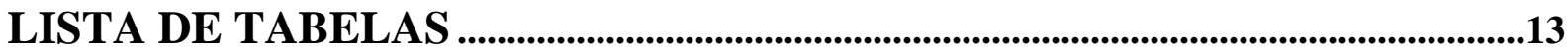

1 INTRODUÇÃO ........................................................................................................................................14

2 REVISÃO DE LITERATURA

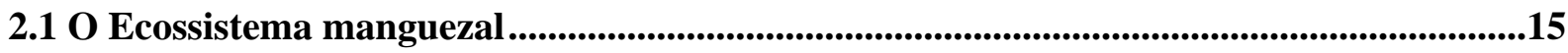

2.2 Importância e diversidade de microrganismos associados ao sedimento de manguezal ..16

2.3 Análise de comunidades microbianas ............................................................. 17

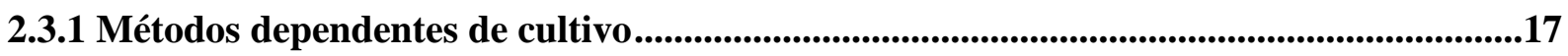

2.3.2 Métodos independentes de cultivo ...................................................................19

2.4 Microrganismos como fonte de recursos biotecnológicos e enzimas microbianas ............21

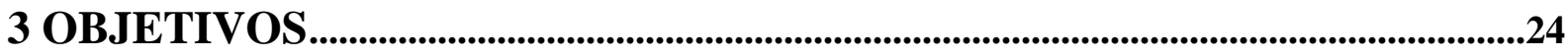

3.1 Objetivos gerais ...............................................................................................................................................24

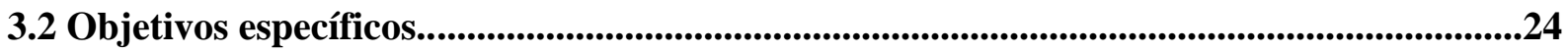

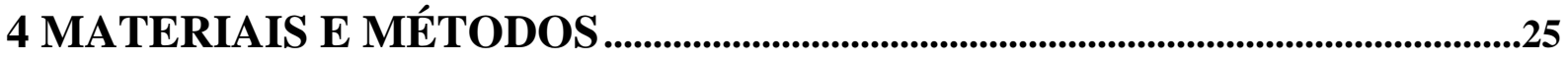

4.1 Local de coleta ....................................................................................................................................................25

4.2 Amostragem e pontos de coleta ......................................................................................................25

4.3 Isolamento de bactérias do solo de manguezal ..............................................................................26

4.4 Extração de DNA de Culturas Bacterianas......................................................................................26

4.5 Amplificação do16S DNAr................................................................................................................26

4.6 Obtenção dos perfis de restrição do 16S DNAr (ARDRA) ....................................................27

4.7 Identificação das UTOs por perfis de ácidos graxos de membranas celulares (MIDI-

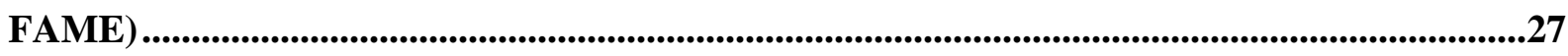

4.8 Avaliação do potencia biotecnológico dos isolados obtidos .............................................28

4.8.1 Determinação da atividade amilolítica .............................................................................................28

4.8.2 Determinação da atividade proteolítica..........................................................................................28

4.8.3 Determinação de Atividade esterásica...........................................................................................28

4.8.4 Determinação da Atividade lipolítica .............................................................................29

4.9 Análise das comunidades bacterianas por meio da técnica de PCR-DGGE.......................29 
4.10 Análise estatística dos dados............................................................................................................30

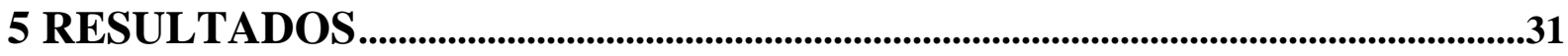

5.1 Isolamento, análise do sedimento e caracterização molecular e identificação da

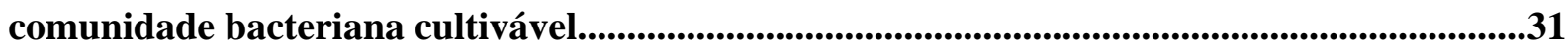

5.2 Avaliação do potencial biotecnológico na produção de enzimas pelas bactérias isoladas

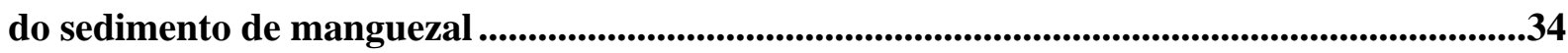

5.3 Diversidade da comunidade bacteriana por meio de técnica independente de cultivo.....38 5.4 Análise dos fatores ambientais determinantes da composição da comunidade bacteriana

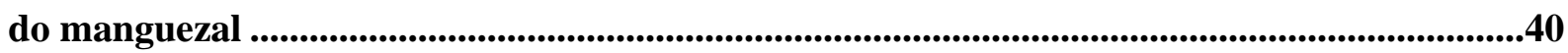

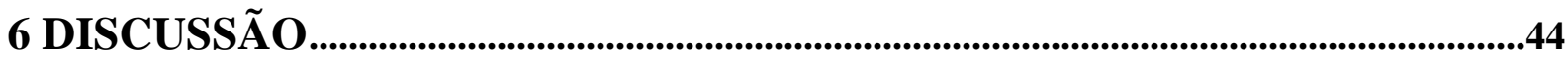

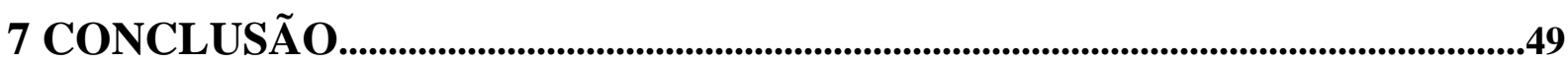

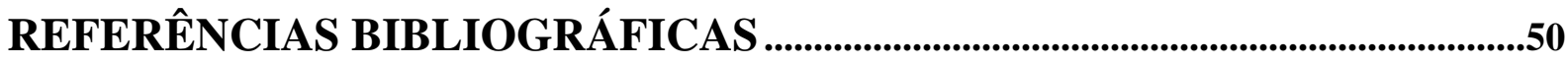




\section{RESUMO}

DIAS, A. C. F., Diversidade de bactérias do sedimento de manguezal da Ilha do Cardoso - Cananéia - São Paulo 2008. 61f. Dissertação (Mestrado em Biotecnologia). Programa de Pós-Graduação Interunidades em Biotecnologia USP/Instituto Butantan/IPT, Universidade de São Paulo, São Paulo, 2008.

O presente trabalho busca entender a dinâmica de comunidades bacterianas cultiváveis e não cultiváveis do ecossistema do manguezal e prospectar nesse ambiente ainda inexplorado, um possível potencial biotecnológico. Os manguezais são áreas localizadas nas planícies de inundação das marés, sendo um dos ambientes naturais mais degradados no Brasil. Nessas áreas ocorre contaminação por diferentes produtos químicos resultando em impactos nas comunidades locais. Por serem ecossistemas abertos, ou seja, apresentarem interface entre o continente, oceano e atmosfera, os manguezais apresentam um solo rico em matéria orgânica proveniente das terras continentais e de bacias hidrográficas, que acessam a zona costeira pelas chuvas e pelos rios. A comunidade microbiana deste ecossistema é altamente diversa e produtiva, decompondo continuamente os resíduos vegetais e mineralizando-os por fim, a nitrogênio, fósforo e outros nutrientes que podem ser usados pelas plantas. No entanto, pouco se conhece sobre a comunidade bacteriana que se desenvolve nos manguezais e esse trabalho tem como objetivo estudar a comunidade bacteriana do manguezal da Ilha do Cardoso-SP. As amostras de sedimentos foram retiradas de duas profundidades (010 e 30-40 cm) no inverno e no verão. Foram isoladas 238 bactérias, das quais uma triagem inicial demonstrou diferentes perfis de produção enzimática (com atividades amilolítica, proteolítica, lipolítica e esterásica), o que sugere grande potencial biotecnológico desse ambiente. Essa comunidade bacteriana foi caracterizada genotipicamente por meio da técnica de ARDRA, onde foram obtidos 10 ribotipos, que após identificação por meio do perfil de ácidos graxos (MIDI-FAME), mostrou que os gêneros Vibrio, Listonella, Aeromonas, Microbacterium, Dermabacter, Brevibacterium, Paenibacillus Staphylococcus, Kurthia, Bacillus, Nesteronkonia, Kytococcus, Kocuria e Rothia foram os predominantes nos sedimentos avaliados. As espécies bacterianas cultiváveis e as não cultiváveis foram também avaliadas por meio da técnica de PCR-DGGE, onde utilizou-se oligonucleotídeos seletivos para Actinobacterias, Alfa e Beta Proteobacteria, Pseudomonas spp. e Paenibacillus spp., além do iniciador universal para Bacteria. A análise multivariada de redundância (RDA) permitiu verificar a relação dos perfis obtidos das amostras com os fatores ambientais. Verificou-se uma diferente distribuição dos grupos de Alfa e Beta Proteobacteria em relação à sazonalidade, enquanto que a profundidade de amostragem mostrou ser essencial no perfil das comunidades totais, Alfaproteobacteria, Betaproteobacteria e Actinobacterias.

Palavras-chave: Ecologia Microbiana, análise multivariada, DGGE, ARDRA, RDA. 


\begin{abstract}
DIAS, A. C. F., Bacterial Diversity in sediment from Mangrove the cardoso Island - cananeia- são Paulo 2008. 61f. Dissertação (Mestrado em Biotecnologia). Programa de Pós-Graduação Interunidades em Biotecnologia USP/Instituto Butantan/IPT, Universidade de São Paulo, São Paulo, 2008.

The objective of the present work is to understand the dynamic of the culturable and non-culturable bacterial community present in the mangrove ecosystem and also to explore the biotechnological potential of bacteria present in this environmental. Mangroves are located in areas which receive water from the ocean, and are one of the most degraded environments in Brazil. In such areas it is commonly observed the contamination by different chemical products, resulting in an impact on the resident community. Due to be considered as open ecosystems located in the interface of the ocean, terrestrial area and atmosphere, the mangroves present a soil with high content of organic matter, originated in the terrestrial part and are brought to the coastal area by the rain. The microbial community in this ecosystem is very diverse and active, mainly in the degradation of organic matter, and mineralizing the nutrients as nitrogen, phosphorus and others, making it available for plants. However, little is known about bacterial community which develops in mangroves. This work studies the bacterial community found in the mangrove located at Ilha do Cardoso-SP. Sediment samples were obtained from two depths $(0-10$ e 30-40 cm) in winter and summer seasons and further analyzed. A total of 238 bacteria were isolated and characterized for the enzimatic production profiles (amilolytic, proteolytic, esterasic and lipase activity) suggesting an important biotechnological potential found in this environment. The isolated bacteria were genotipically characterized by ARDRA, and 10 ribotypes was obtained and further identified by fatty acids methyl esters as the genera Vibrio, Listonella, Aeromonas, Microbacterium, Dermabacter, Brevibacterium, Paenibacillus Staphylococcus, Kurthia, Bacillus, Nesteronkonia, Kytococcus, Kocuria e Rothia. Culturable and non culturable bacteria were also assessed by PCR-DGGE, where the usage of specific primers for Actinobacteria, Alfa and Betaproteobacteria, Pseudomonas spp., Paenibacillus spp. and Bacteria universal primers. Multivariated redundance analysis allowed to verify the main factors determining the bacterial communities patterns found on samples. It was a verified a seasonal distribution of Alfa and Betaproteobacteria groups while the sampled depth was determinant for the total bacterial community composition, and also influenced the Alfaproteobacteria, Betaproteobacteria e Actinobacteria profiles.
\end{abstract}

Key words: Microbial Ecology. Multivariate analysis. DGGE. ARDRA. RDA 


\section{LISTA DE FIGURAS}

Figura 1. Foto aérea do local da coleta na Ilha do Cardoso-Cananéia .25

Figura 2. Gel de agarose com os perfis de bandas dos principais grupos obtidos pela digestão com a enzima de restrição HaeIII. .32

Figura 3. Gráfico comparativo com a ocorrência de haplótipos em porcentagens . .33

Figura 4. Atividades enzimáticas das linhagens testadas correlacionando os pontos e a profundidade amostrada .35

Figura 5. Atividades enzimáticas das linhagens testadas correlacionando as profundidades amostradas .36

Figura 6. Dendograma de similaridade das amostras com base no gel de DGGE do domínio Bacteria 38

Figura 7. Dendograma de similaridade das amostras com base no gel de DGGE das classes: Alfa e Beta Proteobacteria e Actinobacteria. .39

Figura 8. Dendrograma de similaridade das amostras com base no gel de DGGE da população de Paenibacillus spp. e Pseudomonas spp. .40

Figura 9. Agrupamento das amostras de sedimento de manguezal pela análise de Redundância (RDA) e relação com fatores ambientais determinantes da comunidade bacteriana total (Domínio Bacteria) obtido por DGGE.

Figura 10. Agrupamento das amostras de sedimento de manguezal pela análise de Redundância (RDA) e relação com fatores ambientais determinantes da comunidade Alfa e Beta Proteobacteria e Actinobacteria obtido por DGGE.

Figura 11. Agrupamento das amostras de sedimento de manguezal pela análise de Redundância (RDA) e relação com fatores ambientais determinantes da população de Paenibacillus spp. e Pseudomonas spp. obtido por DGGE. 


\section{LISTA DE TABELAS}

Tabela 1. Médias de contagem de colônias com letras diferentes calculadas estatisticamente pelo teste Tukey $(5 \%)$

Tabela 2. Análises físico-químicas das amostras coletadas do sedimento de manguezal................32

Tabela 3. Bactérias obtidas dos isolamentos a partir de amostras de sedimentos do manguezal, identificadas por perfil de ácidos graxos (FAME) . .34

Tabela 4. Representação das atividades enzimáticas extracelulares comparando a média dos halos de degradação de isolados dos três grandes grupos encontrados no sedimento de

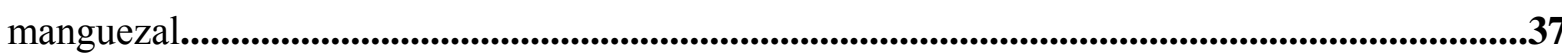




\section{INTRODUÇÃO}

Manguezal é um ecossistema típico de ambiente tropical situado na transição entre a terra e o mar, onde a vegetação é dominada através de espécies de planta típicas do ambiente. Este ecossistema é caracterizado por inundações periódicas das marés que demonstram fatores ambientais como salinidade e disponibilidade de nutriente altamente variável com o passar do tempo, conferindo a este ecossistema características particulares.

A descrição filogenética e funcional da diversidade microbiana neste ecossistema é um assunto importante em comparação a outros ambientes. A importância da diversidade microbiana em tal ecossistema origina de sua importância relacionada a fatores como a presença de poluente. Além disso, a descrição e a distribuição da diversidade bacteriana em um manguezal permite entender melhor a funcionalidade bacteriana e interações microbianas nesse ecossistema. Dentro das condições particulares de um manguezal e a adaptação de espécies bacterianas a tais condições, o manguezal representa uma fonte potencial de recursos biotecnológicos a serem explorado. Tal potencial inclui a descoberta de novas espécies bacterianas capazes de produzir enzimas com aplicações úteis para qualquer aspecto da vida humana, agricultura e industrial.

A avaliação da diversidade bacteriana é altamente dependente da metodologia aplicada. Além do isolamento e caracterização dos isolados bacterianos, métodos independentes de cultivo podem dimensionar a comunidade bacteriana encontrada neste ecossistema. O DGGE é uma técnica útil por investigar as comunidades bacterianas em uma aproximação independente de cultivo, e foi aplicado para estudar as comunidades bacterianas em ambientes diferentes. Esta técnica mostrou ser eficiente na análise de variações de comunidades microbianas devido à presença de agroquímicos, poluentes e condições nutricionais da planta.

Este trabalho teve como objetivo descrever grupos bacterianos cultiváveis e não cultiváveis de sedimentos de manguezal e avaliar a produção enzimática das linhagens isoladas. Esta pesquisa pretendeu determinar os fatores ambientais principais que influenciam na composição de comunidades bacterianas no sedimento do manguezal. 


\section{REVISÃO DE LITERATURA}

\subsection{O Ecossistema manguezal}

O ecossistema manguezal é um ambiente único, dominado pela vegetação de mangue que possui desenvolvimento morfológico-biológico e adaptações ecofisiológicas especializadas para a sobrevivência neste ecossistema onde condições extremas são encontradas como salinidades elevadas, influência das marés, ventos fortes, temperaturas altas, sedimentos lodosos e anaeróbios (FELLER, 1996; KATHIRESAN e BINGHAM, 2001).

Os manguezais estão localizados na zona de transição entre os ecossistemas marinhos e terrestres em regiões intertropicais e são reconhecidos como altamente diversos e produtivos. Os manguezais servem de abrigo para vários organismos, assim formando comunidades complexas que oferecem proteção ao ambiente litorâneo (SJOLING et al., 2005; BRITO et al., 2006; ZHOU et al., 2006). Os ecossistemas de florestas tropicais, recifes de corais e manguezais estão entre os mais produtivos do planeta. Nos últimos 20 anos, observou-se que aproximadamente $50 \%$ dos manguezais do globo vêm sendo destruídos devido à exploração de madeira, crustáceos, cultivo de arroz e desenvolvimento urbano. Acredita-se que pela taxa atual de destruição os manguezais desaparecerão em aproximadamente 50 anos (HOLGUIN et al., 2006).

Os manguezais ocorrem no Brasil por quase toda a extensão da orla marítima de forma quase contínua, dependendo das condições fisiológicas do ambiente; começam no extremo norte (Oiapoque) e se estendem até Santa Catarina (Laguna). Somente o Estado do Rio Grande do Sul não possui vegetação típica de mangue (SHAEFFER-NOVELLI, 1995).

Estes ambientes marcados por inundações periódicas da água do mar, variações de salinidade, escassez de oxigênio e solos lodosos, constituem-se importantes transformadores de nutrientes em matéria orgânica e produtores de bens e alimentos, o que evidencia seu papel sócioeconômico (DINERSTEIN et al., 1995). Neste contexto, a Ilha do Cardoso, localizada no município de Cananéia, foi determinada como Parque Estadual em 1962, com área de 22.500ha e engloba grande variedade de ambientes associados à costa brasileira, como mata atlântica, restinga, duna, manguezal, estuário, praia e costão rochoso (MENEZES e SHAEFFERNOVELLI, 1994), os quais têm sido estudados para uma melhor compreensão do papel destes ambientes na manutenção do equilíbrio na região. 


\subsection{Importância e diversidade de microrganismos associados ao sedimento de manguezais}

Em todo o planeta os microrganismos representam a forma de vida mais diversificada e abundante (WHITMAN et al., 1998). Por meio da análise da diversidade microbiana do solo com técnicas de hibridização de DNA, tem sido estimado que em um grama de solo existam aproximadamente 10.000 genomas (TORSVIK et al.; 1998).

O funcionamento e a diversidade dos ecossistemas vêm diminuindo pela ação do homem, acarretando extinção de espécies essenciais na manutenção destes ambientes e resultando em desequilíbrios ecológicos (AZEVEDO, 1998). Como exemplo deste efeito pode-se citar a diversidade microbiana do solo, que quando afetada pode reduzir a ciclagem de nutrientes e alterar o crescimento das plantas (REBER, 1992). A existência e a diversidade de seres vivos no planeta estão intimamente ligadas à diversidade e à atividade metabólica de microrganismos na natureza (LOVELOCK, 1988; STOLZ et al., 1989; TRÜPER, 1992). O papel dos microrganismos na manutenção dos processos biológicos é conhecido, sabendo-se que participam de processos ecológicos bastante importantes, tais como a fotossíntese oxigênica, ciclagem de matéria orgânica, ciclos biogeoquímicos e manutenção da fertilidade e estrutura de solos (STOLZ et al., 1989; TRÜPER, 1992).

Em manguezais tropicais, bactérias e fungos constituem $91 \%$ da biomassa microbiana total, considerando que algas e protozoários representam apenas $7 \%$ e $2 \%$ respectivamente (ALONGI, 1988; BANO et al., 1997). Bactérias pertencentes aos gêneros Azospirillum, Azotobacter, Rhizobium, Clostridium e Klebsiella foram isoladas dos sedimentos, rizosferas e superfícies de raízes de várias espécies vegetais dos manguezais (SENGUPTA e CHAUDHURI 1990 e 1991). Adicionalmente várias espécies da ordem Actinomicetales vêm sendo encontradas em habitats de manguezais e marinhos (KALA e CHANDRIKA, 1993) onde têm se mostrado importantes produtores de fármacos (VIKINESWARY et al., 1997; JENSEN et al., 2005). A ocorrência também foi observada em esponjas, onde Actinobacterias foram verificadas interagindo com quatro espécies de esponjas do mar no sul da China. Neste mesmo trabalho, além de Actinobactérias foram também encontrados membros dos grupos Proteobacteria (Alfa, Beta e Gamma) e Firmicutes (LI et al., 2006).

Shome et al. (1995) isolaram trinta e oito bactérias distintas de folha de mangue e sedimentos ao sul da Índia e caracterizaram essa comunidade bacteriana, na sua maioria Grampositiva $(76.3 \%)$, móveis (87\%), fermentadores (82.1\%), pigmentados $(31 \%)$ e resistentes a antibióticos (100\% contra polimixina B e 50\% contra clorafenicol).

A alta ocorrência de bactérias resistentes a antibioticos pode estar ligada a eventos de contaminação dos manguezais. Os sedimentos de manguezais têm sido contaminados com o uso 
de antibacterianos no cultivo de camarões e peixes e os resíduos desses compostos têm promovido importante impacto no ambiente. Um modelo para essa análise foi o desenvolvido na Itália onde foi avaliada a incidência de antibióticos usando uma linhagem de Vibrio fischeri como padrão de resistência (LALUMERA et al., 2004). Em outra situação, foram isoladas do sedimento de manguezal do Vietnã, linhagens de Bacillus sp. e Vibrio sp. resistentes a diversos antibióticos (LE et al., 2005).

Atualmente, novas técnicas de biologia molecular têm permitido uma descrição mais completa da diversidade bacteriana associada a diferentes manguezais. Em um estuário do Reino Unido (River Colne), onze amostras de sedimentos foram analisadas por PCR-DGGE e análise multivariada, correlacionando fatores ambientais como salinidade, sulfato e nitrato com a comunidade bacteriana do ambiente, tendo como população residente, microrganismos do gênero Desulfobulbus mostrando que no inverno e verão as populações variam e se mostram sensíveis à disponibilidade de nutrientes avaliados (HAWKINS et al., 2007).

De maneira similar, amostras de superfícies $(0-1,1-2,2-4$ e 4-10 cm) de sedimentos de dois manguezais com diferentes vegetações, Pambala-Chilaw no Sri Lanka e Pichavaram, localizados na Índia, foram investigados por análise de perfil de ácidos graxos (PFLA) de bactérias relacionadas a fontes diferentes de matéria orgânica como fitoplânctons, microfitobentos e material derivado da influência marítima. Os dados demonstram que a origem do carbono como substrato para o metabolismo bacteriano varia amplamente em profundidades e locais no manguezal e sugere que a mineralização da matéria orgânica não pode ser estimada diretamente do ecossistema levando em conta as diversas outras fontes (BOUILLON et al., 2004). Na baía de Bengal - Índia, em diversos pontos a incidência de metano atmosférico foi mensurada mostrando diferenças significativas em relação à freqüência de inundação pelas águas continentais e marítimas, indicando intensa oxidação e competição de bactérias metanogênicas por sulfato e nitrato (BISWAS et al., 2007).

\subsection{Análise de comunidades microbianas}

\subsubsection{Métodos dependentes de cultivo}

A análise detalhada de diversidade microbiana dentro de um ambiente pode ser dividida em duas categorias amplas: estudos dependentes e independentes de cultivo (JUCK et al., 2000). Em métodos dependentes de cultivo, bactérias são isoladas de amostras ambientais em meio de cultura. Neste caso, a diversidade das comunidades acessadas é normalmente determinada por caracterização fenotípica e genotípica dos isolados obtidos. O problema intrínseco a este tipo de 
analise é a seleção que ocorre no isolamento para bactérias que possuem a capacidade de se desenvolver nas condições aplicadas no isolamento, como meio de cultura, temperatura e atmosfera de incubação. Apesar do avanço em técnicas de cultivo, ainda não é possível cultivar a grande maioria de espécies bacterianas em condições comuns de laboratório, estado dessa forma, a caracterização desses isolados microbianos sujeita a críticas, pois depende de condições ambientais específicas (BAKONYI et al., 2003).

Considerando desta forma que as técnicas de isolamento normalmente utilizadas para avaliar a comunidade microbiana não permitem o estudo de microrganismos não cultiváveis, ocorre uma restrição do estudo somente a grupos já conhecidos. Desta forma, para se avaliar comunidades microbianas não cultiváveis, tem sido utilizadas técnicas moleculares baseadas na analise de moléculas biológicas extraídas diretamente de amostras ambientais.

Alguns métodos bioquímicos (PFLA) e moleculares (DGGE, T-RFLP) vêm sendo usados para investigar a diversidade microbiana e mudanças dentro da estrutura da comunidade microbiana em diversos ambientes. Métodos moleculares são mais sensíveis que os bioquímicos e fisiológicos, porém qualitativamente os resultados são bastante semelhantes (SINGH et al., 2006). Em solos convencionais e de rotações de culturas do Cerrado brasileiro, foram amostradas duas profundidades $(0-5$ e $5-10 \mathrm{~cm})$ e analisadas por DGGE, demonstrando que a técnica juntamente com marcadores fisiológicos é eficiente no estudo da dinâmica da ecologia microbiana (PEIXOTO et al., 2006). Amostras de quatro solos distintos de Lower Saxony-Alemanhã foram comparadas por três técnicas moleculares (DGGE, T-RFLP, SSCP) mostrando serem eficientes e conduzindo a resultados semelhantes (SMALLA et al., 2007).

A maioria destas técnicas se baseia na avaliação da diversidade dos genes ribossomais, sendo no caso das bactérias o gene mais utilizado o 16S DNAr (AMANN et al., 1995). Vale ressaltar que técnicas moleculares baseadas na diversidade deste gene podem ser aplicadas na genotipagem de isolados bacterianos, como a análise por restrição de fragmentos do 16S DNAr (ARDRA - Análise de Restrição do DNA Ribossomal), que tem sido usada como ferramenta molecular rápida, barata e eficaz no intuito de filtrar, agrupar e diferenciar o grande número de colônias obtidas em isolamento (HEYNDRICKX et al., 1996; RAMSING et al., 1996; TESKE et al., 1996; VAN ELSAS et al., 1998; MUYZER, 1999; OVERMANN et al., 1999; GURTNER et al., 2001). Em águas do mar na Antártida, a utilização do ARDRA permitiu a análise da diversidade com o agrupamento das linhagens isoladas em 52 grupos, a partir da utilização da enzima AluI. Uma avaliação posterior por RAPD demonstrou a variabilidade genética desses grupos (MICHAUD et al., 2004), o que também foi feito utilizando o perfil ARDRA, em linhagens isoladas de Brevibacterium spp. (SEYLER et al., 2007). 
Heyndrickx et al. (1996) obtiveram padrões distintos de fragmentos usando a enzima de restrição HaeIII na separação dos gêneros Bacillus e Paenibacillus. A técnica foi utilizada em sedimentos de recifes de corais na Austrália (GUTHRIE et al., 2000), na análise filogenética do gênero Bacillus fixadores de nitrogênio em solo agrícola (CHECNÉBY et al., 2000), em solos contaminados com cobre (SMIT et al., 1997) e cromo (VITI e GIOVANNETTI, 2005). Recentemente $\mathrm{Wu}$ et al. (2006) por meio de enzimas de restrição (ARDRA) usando Bacillus probióticos comerciais e Paenibacillus, Brevibacillus e Bacillus da ATCC (American Type Culture Collection) desenharam iniciadores específicos para facilitar a identificação desses microrganismos no ambiente.

\subsubsection{Métodos independentes de cultivo}

Considerando a análise direta de amostras ambientais, das metodologias baseadas no gene 16S DNAr para o estudo de populações microbianas complexas, o DGGE (Gradiente Desnaturante em Gel de Eletroforese) identifica diferenças baseadas no comportamento desnaturante da dupla fita de DNA. Neste caso, o ambiente desnaturante é criado pela combinação uniforme de temperatura de corrida à $60^{\circ} \mathrm{C}$ e um gradiente desnaturante linear de uréia e formamida (MUYZER et al., 1993; HEUER e SMALLA, 1997). O DGGE tem recebido especial atenção por ter sido utilizado em diferentes habitats naturais com sucesso na detecção de variações na comunidade microbiana decorrente da presença de agroquímicos (FANTROUSSI et al., 1999), poluentes (BRIM et al., 1999), variação nutricional e fisiológica da planta hospedeira (HENCKEL et al., 1999; YANG e CROWLEY, 2000) e para estudar a comunidade microbiana associada às plantas transgênicas (HEUER e SMALLA, 1997) e endofítica (GARBEVA et al., 2001; ARAÚJO et al., 2002; ANDREOTE et al., 2004 e 2006; LACAVA et al., 2006 e 2007). Associada aos microarranjos de DNA, a técnica permitiu a avaliação de comunidades microbianas anaeróbicas associadas à degradação de tolueno e etil-benzeno (KOIZUMI et al., 2002), mostrando bactérias cultiváveis e não cultiváveis presentes no ambiente. Dessa forma, esta técnica se mostra eficiente na avaliação de alterações em comunidades microbianas frentes à alterações físico-químicas do ambiente.

Considerando ambientes marinhos, a técnica de DGGE tem sido usada como ferramenta para avaliar e monitorar a diversidade microbiana destes ambientes em trabalhos recentes, que avaliaram a comunidade bacteriana em estuários no Brasil, monitorando as comunidades bacterianas (SOUZA et al., 2006). De maneira similar, a extração de DNA de amostras do sedimento e águas do pacífico foi testada por diversas metodologias, demonstrando que a 
qualidade do DNA interfere em uma boa reação em cadeia da polimerase (PCR) contribuindo para melhor avaliação da comunidade acessada (NIEMI et al., 2001; WEBSTER et al., 2003).

Ainda em ambientes aquáticos, a análise de comunidades bacterianas por PCR-DGGE e biblioteca de DNAr 16S, foi utilizada para avaliar a diversidade microbiana de quatro lagos na Bélgica, onde a concentração de fósforo variou nas amostras estudadas. Em três dos lagos a comunidade predominante foi a de Betaproteobacteria e em um, foi observada a predominância de actinobacterias (GUCHT et al., 2005).

Em laboratório, por meio de análises independentes de cultivo e multivariadas, solos agrícolas de diversas culturas foram correlacionados a fatores como temperatura de incubação, pH, matéria orgânica, amônia e nitrato. Foi observado que quando controlados, estes fatores interferem na composição da comunidade bacteriana (COOKSON et al., 2007). Nos Estados Unidos - Minnesota, amostras de sedimento de reservas permanentes analisadas também em laboratório, relacionam as comunidades bacterianas e metanotróficas à vegetação, mostraram 23 populações diferentes encontradas, sendo 90\% não cultiváveis (JOURNETT et al., 2007).

Devido à importância e a ampla distribuição de manguezais no Brasil alguns trabalhos, envolvendo combinações de técnicas independentes de cultivo e isolamento de microrganismos com potencial biotecnológico, vêm sendo realizados. Em sedimentos de manguezal da Baía de Guanabara - Rio de Janeiro contaminado por petróleo, foram encontradas bactérias dos grupos Gama e Alfaproteobacteria e Actinobacteria, as quais são eficientes na degradação de hidrocarbonetos (BRITO et al., 2006). Em análise por DGGE e biblioteca de DNAr 16S de esponjas, foi observado que membros dos grupos Proteobacteria, Actinobacteria e Firmicutes dentre outros (HENTSCHEL et al., 2006) e linhagens de Vibrio sp., Bacillus sp. formam associação simbiôntica com poríferos (WEHRL et al., 2007).

A comunidade bacteriana em amostras de água do ecossistema de manguezal da reserva permanente de Guandu, situada na ilha da Tailândia, foi estudada por meio de análises independente de cultivo (Biblioteca de DNAr 16S) e mostrou a ocorrência de diferentes grupos bacterianos sendo: $34 \%$ de Betaproteobacteria, 29\% de Alfaproteobacteria, $19 \%$ de Gamaproteobacteria, 12\% de Epsilonproteobacteria, 1\% de Actinobacterias e Firmicutes onde 4\% ainda não estão descritas (LIAO et al., 2007). As amostras de sedimentos de manguezais coletadas na reserva permanente de Futian - China foram analisadas, mostrando que 63\% dos clones pertencem às Proteobacteria, $9 \%$ Actinobacteria, 6\% Chloroflexi, 5\% Firmicutes, enquanto que os outros grupos representaram menos de 1\%. (LIANG et al., 2007).

A análise estatística multivariada para técnicas independentes de cultivo tem sido usada para o melhor entendimento de fatores correlacionados com comunidades bacterianas. No estudo de sete plantas perenes em microcosmo na Irlanda, a análise da disponibilidade e quantidade de 
nitrogênio na planta afetou a diversidade bacteriana no solo, mas não na planta (KENNEDY et al., 2004). No parque estadual de Illinois - Chicago - Estados Unidos, a biomassa microbiana foi amostrada de solos em diferentes pradarias com vegetações distintas e perturbações físicoquímicas. A análise de redundância (RDA) correlacionando variáveis como umidade, carbono, enxofre e disponibilidade de água, mostrou que a comunidade mudou significativamente em solos perturbados, sendo que métodos de restauração levariam décadas pra restabelecer a comunidade indígena (MCKINLEY et al., 2005). A análise por PCR-DGGE de comunidades de bacterioplânctons em seis lagos localizados na Suécia no verão e inverno, demonstrou por meio do RDA diferenças nas comunidades bacterianas em lagos com mesma área de drenagem comparando com lagos com diferentes locais de drenagens (LINDSTRÖM et al., 2005).

A heterogeneidade ambiental e a relação espacial no ambiente junto a fatores físicos e químicos foram avaliadas por RDA em sistemas distintos usando como padrão de comparação bactérias do gênero Burkolderia spp., mostrando que condições controladas podem não afetar a comunidade bacteriana (RAMETTE e TIEDJE, 2007).

\subsection{Microrganismos como fonte de recursos biotecnológicos e enzimas microbianas}

A biodiversidade consiste na amplitude numérica e qualitativa de macro e microrganismos presentes nos mais variados ambientes da biosfera. E a biodiversidade é a base genética da qual a biotecnologia se vale para desenvolver processos e produtos de interesse econômico e/ou social (AZEVEDO, 1998). Considerando esse fator e a capacidade de microrganismos realizarem importantes transformações metabólicas no ambiente, estes podem ser uma importante fonte de produtos úteis ainda inexplorados. Dentre estes produtos, podem ser encontradas aplicações como o biocontrole de doenças e pragas, a degradação de resíduos e a promoção do crescimento vegetal realizada por meio da fixação de nitrogênio e/ou da solubilização de fosfato. Adicionalmente, podem ser encontrados novos fármacos, corantes, enzimas e ácidos orgânicos. Considerando que o sucesso da descoberta de novos produtos consiste em obter e descrever microrganismos ainda não descritos, torna-se imprescindível sua busca em ambientes e condições ainda pouco explorados (AZEVEDO, 1998).

As enzimas microbianas têm sido utilizadas pela indústria e a busca por tais metabólitos tem se tornado alvo de vários grupos de pesquisa. A escolha dos microrganismos como base exploratória se deve à estabilidade de suas características e sua diversidade de atividade catalítica em relação às encontradas em outros organismos vivos, o que melhora e otimiza a qualidade do processo. A utilização de enzimas como amilases, lipases, proteases, celulases, dentre outras, é bastante ampla nas indústrias de alimentos, bebidas, farmacêutica, têxtil e no tratamento de 
resíduos. Assim sendo, tais enzimas têm alvo de melhoramento onde moléculas melhores e mais eficientes têm sido obtidas principalmente de microrganismos (CHANDRASEKARAN, 1997).

Desta maneira, sabe-se que os microrganismos marinhos, em função da adaptação ao habitat, apresentam uma versatilidade metabólica que suplanta de longe àquela encontrada nos microrganismos do solo ou associados às plantas. Algumas linhagens de microrganismos marinhos são conhecidas por produzir grandes quantidades de quitinases, glicanases e DNA polimerases, que são estáveis em diferentes condições ambientais. Assim sendo, torna-se oportuna a busca de microrganismos neste ambiente aquático, composto por uma grande riqueza de novas espécies, que podem servir como novidades de interesse à biotecnologia (CHANDRASEKARAN, 1997).

As proteases bacterianas são as enzimas mais importantes dentre as produzidas por microrganismos e consistem em enzimas degradadoras de complexos protéicos, como a serinaprotease, a cisteína (tiol) protease, as aspártico-proteases e as metalo-proteases. Estas enzimas constituem o maior grupo de enzimas industriais, compondo cerca de $60 \%$ do mercado de enzimas (NASCIMENTO e MARTINS, 2004). O mercado das proteases atualmente está voltado para a produção de detergentes, o que exige a estabilidade dessas enzimas em diferentes temperaturas e pHs, além da compatibilidade com agentes oxidante e surfactantes que são incluídos no processo. As proteases microbianas mais utilizadas são provenientes de Bacillus e mais recentemente, novos microrganismos de ambientes diferentes como o estuarino, têm sido estudados na busca de novas formas destas enzimas. VENUGOPAL e SARAMMA (2006) isolaram uma linhagem de Vibrio fluvialis de sedimento de manguezais do sul da Índia que apresentou capacidade de produzir uma protease alcalina com as características desejadas já citadas.

As alfa-amilases são enzimas que degradam amido a partir da catálise de ligações glicosídicas $\beta-1-4$. As amilases são uma das mais importantes enzimas industriais na conversão de amido a xarope de açúcar e produção de ciclodextrinas para a indústria farmacêutica (SIVARAMAKRISHNAN et al., 2006).

Ainda no ranqueamento das enzimas de interesse industrial, depois das proteases e carboidrases, aparecem as lipases (triacilglicerol-acilhidrolase) como terceiro maior grupo em termos de volume de produção e utilização. Seu potencial biotecnológico está relacionado à capacidade de promover a catálise da hidrólise de triglicerídeos e ainda sua síntese a partir de ácidos graxos e glicerol. A principal aplicação das lipases envolve a produção de detergentes, laticínios, processamento de óleos, biotransformações, farmacêuticos, agroquímicos, pesticidas e inseticidas (JAEGER et al., 1997). Apesar de ocorrerem largamente na natureza, apenas as lipases microbianas é que são comercialmente importantes. Espécies de Bacillus e uma variedade de 
gêneros tais como Staphylococcus, Lactobacillus, Streptococcus, Micrococcus, Propionibacterium, Burkholderia, Pseudomonas, Aeromonas e Acinetobacter têm sido destaques na produção de lipases (SHARMA et al., 2001).

As esterases são enzimas que catalisam a hidrólise de ligações éster (esterificação, transesterificação e inter-esterificação) e também são largamente distribuídas em animais, plantas e microrganismos. São distinguidas das lipases porque hidrolisam substratos solúveis ou completamente dispersos. Uma aplicação importante para as esterases, bem como para as lipases e mais recentemente estudada é a degradação do biodiesel. Bactérias com atividade lipolítica têm sido buscadas com o objetivo de promover melhores degradadores desse combustível (JAEGER e EGGERT, 2002). 


\section{OBJETIVOS}

\subsection{Objetivo geral}

O presente trabalho teve como objetivo avaliar a diversidade e produção enzimática da comunidade bacteriana associada ao sedimento do manguezal localizado na Ilha do Cardoso (Cananéia/SP, Brasil).

\subsection{Objetivos específicos}

Os objetivos específicos deste estudo foram:

- Isolar a microbiota associada ao sedimento de manguezal em épocas (inverno e verão) e profundidades (0-10 e 30-40cm) diferentes;

- Agrupar os isolados por ARDRA e identificar as bactérias por meio do perfil de ácidos graxos (MIDI - FAME);

- Caracterizar a atividade enzimática (amilolítica, proteolítica, esterásica e lipolítica) de linhagens isoladas;

- Analisar a diversidade das comunidades de maneira independente de cultivo, acessando comunidades bacterianas totais, Alfa e Beta Proteobacteria, Actinobacteria, Pseudomonas spp. e Paenibacillus spp. utilizando a técnica de DGGE;

- Inferir sobre os fatores ambientais determinantes na composição de testas comunidades por meio de análise multivariada. 


\section{MATERIAIS E MÉTODOS}

\subsection{Local de Coleta}

O presente estudo foi desenvolvido em uma transversal com 340m de extensão ao longo do gradiente de inundação do manguezal localizado no Parque Estadual da Ilha do Cardoso (PEIC). A transversal tem orientação de $180^{\circ} \mathrm{S}$, com início na margem da Baía de Trampandé, estendendo-se até o ambiente terrestre (figura 1).

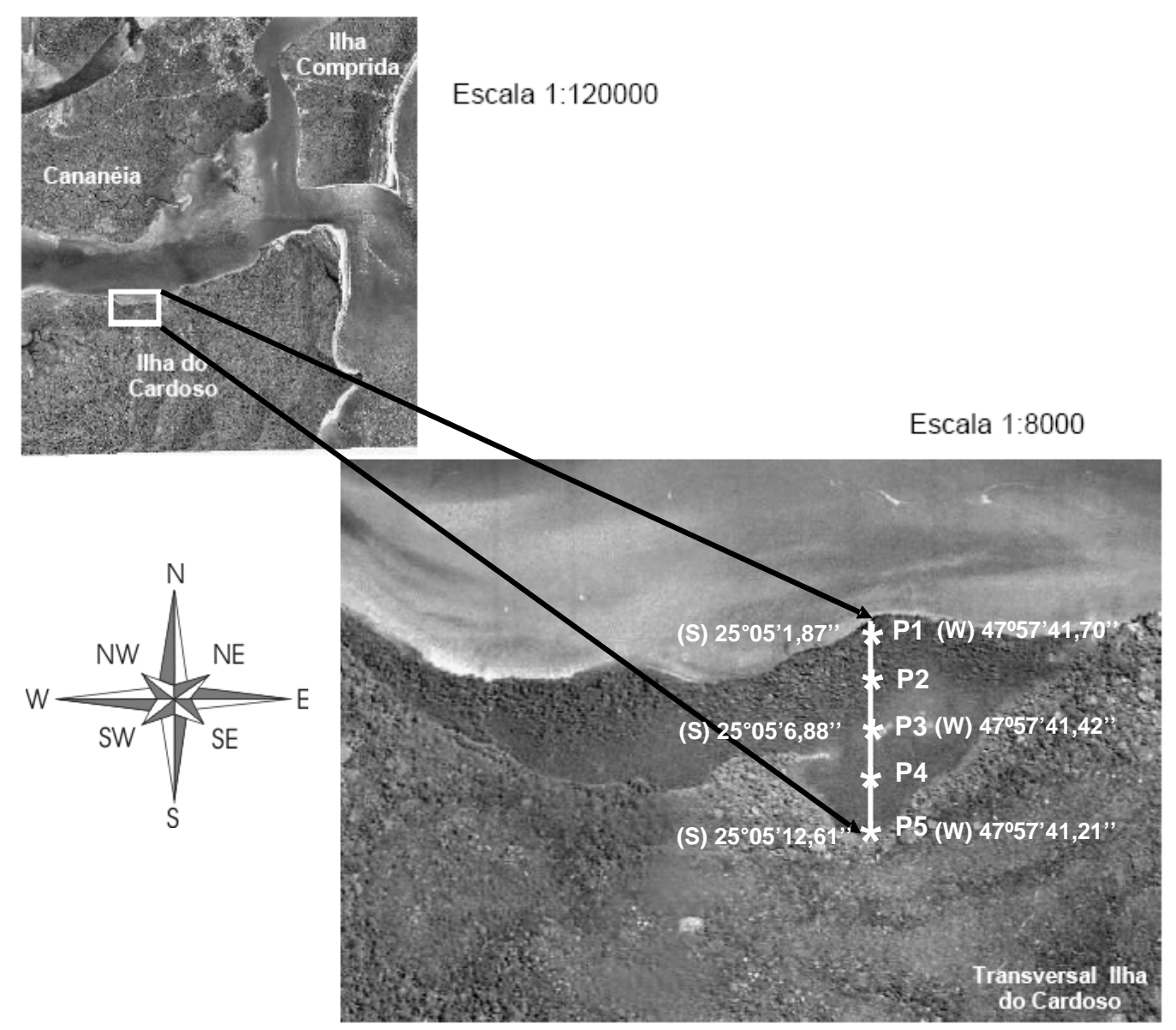

Figura 1 - Foto área do local da coleta na Ilha do Cardoso-Cananéia (Foto: Almeida, 2005).

\subsection{Amostragem e pontos de coleta}

As coletas realizadas incluíram cinco amostras em pontos distintos. Os pontos indicam os locais de coleta onde $\mathrm{P} 1$ esta próximo ao mar, $\mathrm{P} 5$ junto à restinga e $\mathrm{P}$, ponto médio da transversal e suas respectivas coordenadas geográficas (GPS modelo DATUM/SIRGAS 2000) (Figura 1). Em cada ponto foram escolhidas aleatoriamente cinco sub-amostras, que foram acondicionadas em 
sacos plásticos, armazenadas em caixas térmicas com gelo e levadas imediatamente ao laboratório.

Para a coleta das amostras foi utilizado um amostrador de aço inoxidável (um cilindro cortado longitudinalmente com $100 \mathrm{~cm}$ de comprimento e $7 \mathrm{~cm}$ de diâmetro). Foram amostradas duas seções representando as camadas de 0 a $10 \mathrm{~cm}$ e de 30 a $40 \mathrm{~cm}$ de profundidade.

\subsection{Isolamento de bactérias do solo de manguezal}

Depois de misturadas as sub-amostras, $1 \mathrm{~g}$ do sedimento foi colocado em $9 \mathrm{~mL}$ de solução salina $(\mathrm{NaCl} 0.9 \%)$ e agitada por $1 \mathrm{~h}$. Após este período uma diluição seriada foi preparada e alíquotas de $100 \mu \mathrm{L}$ das diluições $10^{-3}, 10^{-4}$ e $10^{-5}$ foram semeadas sobre o meio de cultura TSB (Triptona Soja Agar) 5\% suplementado com Benomyl $20 \mu \mathrm{g} / \mathrm{mL}$, e $\mathrm{NaCl}$ 1,8\%. As placas foram posteriormente incubadas à $28^{\circ} \mathrm{C}$ por 20 dias. Após desenvolvimento das colônias foi realizada a contagem, que foi preferencialmente feita nas placas semeadas com a diluição $10^{-4}$. As colônias obtidas foram purificadas e estocadas em solução de glicerol $20 \%$ em freezer à $-80^{\circ} \mathrm{C}$.

\subsection{Extração de DNA de culturas bacterianas}

As colônias bacterianas obtidas no isolamento foram cultivadas em meio líquido TS (Triptona Soja) sob agitação constante por 24 horas. Posteriormente foram centrifugados $1,5 \mathrm{~mL}$ das culturas bacterianas a $12.000 \mathrm{x}$ g por 10 minutos. O precipitado foi ressuspendido em $500 \mu \mathrm{L}$ de TE e centrifugado por 2 minutos a $12.000 \mathrm{x}$ g. O precipitado foi novamente ressuspendido em $500 \mu \mathrm{L}$ de TE e adicionados $30 \mu \mathrm{L}$ de SDS $10 \%, 0,1 \mathrm{~g}$ de esferas de sílica $(0,1 \mathrm{~mm})$ e agitados em homogeneizador de células por 30 segundos. O DNA foi purificado pelo método de fenolclorofórmio (SAMBROOK et al., 1989) e a sua integridade foi avaliada por meio de eletroforese em gel de agarose $(0,8 \% \mathrm{p} / \mathrm{v})$ a $\left(3\right.$ volts $\left./ \mathrm{cm}^{-1}\right)$ em tampão TEB $1 \mathrm{x}$ e corado com brometo de etídio $\left(1,0 \mathrm{mg} / \mathrm{mL}^{-1}\right)$.

\subsection{Amplificação do 16S DNAr}

A amplificação do 16S DNAr foi realizada por meio da técnica de PCR utilizando-se os oligonucleotídeos universais para o domínio bactéria P027F (5'GAGAGTTTGATCCTGGCTCAG-3') e 1378R (5'CGGTGTGTACAAGGCCCGGGAACG-3'). As reações apresentaram um volume final de $50 \mu \mathrm{L}$ contendo 0,5 a 10 ng de DNA molde; $0,2 \mathrm{M}$ de cada oligonucleotídeo, $0,2 \mathrm{mM}$ de cada dNTP; 3,75mM de $\mathrm{MgCl}_{2}$ e $0,05 \mathrm{U}$ da enzima Taq DNA 
polimerase (Invitrogen) em 20mM de Tris- $\mathrm{HCl}$ pH 8,4 e 50mM KCl. Em todas as reações foram utilizados controles negativos sem o DNA molde.

A reação de amplificação foi realizada em termociclador Perkin-Elmer GeneAmp@ PCR System 9700 programado para realizar uma desnaturação inicial a $94^{\circ} \mathrm{C}$ por 4 minutos, 30 ciclos de desnaturação a $94^{\circ} \mathrm{C}$ por 30 segundos, anelamento a $63^{\circ} \mathrm{C}$ por 1 minuto e extensão de oligonucleotídeos a $72^{\circ} \mathrm{C}$ por 1 minuto, seguida de extensão final a $72^{\circ} \mathrm{C}$ por 7 minutos. Após a amplificação, $5 \mu \mathrm{L}$ da reação de PCR foram avaliados por eletroforese em gel de agarose $(1,2 \%$ $\mathrm{p} / \mathrm{v})$ a 3 volts $/ \mathrm{cm}^{-1}$ em tampão TEB $1 \mathrm{x}$ e corado com brometo de etídio $\left(1,0 \mathrm{mg} / \mathrm{mL}^{-1}\right)$, para visualização de um fragmento de aproximadamente $1350 \mathrm{pb}$ juntamente com o marcador de peso molecular DNA Ladder 1000pb.

\subsection{Obtenção dos perfis de restrição do 16S DNAr (ARDRA)}

A ribotipagem do 16S DNAr foi obtida pela utilização da técnica de ARDRA (Análise de Restrição do DNA Ribossomal). Para isso, $1 \mu \mathrm{g}$ do fragmento de 16S DNAr amplificado foi clivado com a enzima de restrição HaeIII, de acordo com as recomendações do fabricante (Invitrogen). Após a digestão, toda a reação foi analisada por eletroforese em gel de agarose $(2,5 \%$ p/v) em tampão TEB 1x juntamente com o marcador de peso molecular DNA Ladder $100 \mathrm{pb}$ (Life Technologies). Em seguida, o gel foi corado com brometo de etídio $\left(1,0 \mathrm{mg} / \mathrm{mL}^{-1}\right)$, e observado sob luz ultravioleta e fotodocumentado. Perfis diferentes de clivagem foram considerados como diferentes UTOs (unidades taxonômicas operacionais).

\subsection{Identificação das UTOs por perfis de ácidos graxos de membranas celulares (MIDI- FAME)}

Os isolados representantes das diferentes UTOs foram inoculados em meio TSBA ${ }^{\circledR} \mathrm{BBL}$ pelo método das estrias cruzadas e incubados a $28^{\circ} \mathrm{C}( \pm 1)$ por $24 \mathrm{~h}( \pm 2)$. Decorrido este tempo, foi coletado 40mg (4 a 6 alças com capacidade de 10mg) do terceiro quadrante da placa e transferidas para tubos Kimax (100 x 13mm). Foi adicionado $1 \mathrm{~mL}$ do reagente de saponificação, agitado por 10 segundos e incubado em banho-maria $\left(95-100^{\circ} \mathrm{C}\right)$ por 5 minutos. Em seguida os tubos foram resfriados em água e novamente agitados por 10 segundos, retornando ao banho-maria por mais 25 minutos. Após resfriamento em água, foram adicionados $2 \mathrm{~mL}$ do reagente de metilação e os tubos agitados por 10 segundos e colocados em banho-maria $80^{\circ} \mathrm{C}( \pm 1)$ por mais 10 minutos seguido por resfriamento em água. A essa solução foi adicionado $1,25 \mathrm{~mL}$ do reagente de extração e posteriormente levado ao rotator clínico (FISHER M346) por 10 minutos. Com o auxílio de 
pipetas Pasteur, foi descartada a fase inferior (aquosa) e adicionado ao tubo $3 \mathrm{~mL}$ do reagente de lavagem básica, retornando os tubos para o rotator clínico por mais 5 minutos. Ao fim deste tempo, os tubos foram centrifugados a $2000 \times$ g por 3 minutos, quando $2 / 3$ da fase superior $(0,5 \mathrm{~mL})$ foi transferido para os frascos de cromatografia $(2 \mathrm{~mL})$.

\subsection{Avaliação do potencia biotecnológico dos isolados obtidos}

\subsubsection{Determinação da atividade amilolítica}

As bactérias foram crescidas a $28^{\circ} \mathrm{C}$ por 72 horas em meio TSBA $5 \%$ suplementado com $1 \%$ de amido. Após o crescimento bacteriano, foram adicionados $5 \mathrm{~mL}$ de Solução de Iodo (1\%). A presença de um halo incolor em torno da colônia indicou a produção de amilases extracelulares (HANKIN e ANAGNOSTAKIS, 1975).

\subsubsection{Determinação da atividade proteolítica}

Aproximadamente 10mg (uma alçada cheia) das colônias bacterianas foram inoculadas em placas de Petri com o meio de Gelatina ágar, incubadas a $28^{\circ} \mathrm{C}$, por 5 dias (VIEIRA, 1999). Após o crescimento das colônias, o meio foi coberto com solução de Frasier por 2 minutos (SMIBERT e KRIEG, 1994). A atividade proteolítica foi evidenciada pelo aparecimento de uma zona transparente ao redor das colônias, em contraste com a cor branca do meio de cultura.

\subsubsection{Determinação de atividade esterásica}

Para a determinação da atividade esterásica foi utilizado o meio de cultura descrito por (SIERRA, 1957). Após a esterilização do meio de cultura, foi adicionado Tween 80 numa concentração final de $1 \%(\mathrm{v} / \mathrm{v})$. O meio foi então vertido sob placas de Petri esterilizadas e após solidificação, as bactérias previamente crescidas foram inoculadas e a presença de halos claros indicou a atividade esterásica. 


\subsubsection{Determinação da atividade lipolítica}

Para a determinação da atividade lipolítica, foi empregado a mesma metodologia da atividade esterásica, mas substituindo o Tween 80 por Tween 20. A presença de halos de degradação foi observada nos mesmos períodos de tempo (SIERRA, 1957).

\subsection{Análise das comunidades bacterianas por meio da técnica de PCR-DGGE}

Na técnica de PCR-DGGE o DNA extraído diretamente da amostra ambiental foi utilizado para amplificação e posterior separação dos fragmentos gerados em gel com gradiente desnaturante. Desta maneira, os DNAs presente em $0,5 \mathrm{~g}$ de sedimento foram extraídos utilizando o Kit MoBio UltraClean ${ }^{T M}$ soil DNAt (MoBio Laboratories, EUA), de acordo com o protocolo fornecido pelo fabricante. A quantidade e a qualidade do DNA extraído foram avaliadas em gel de agarose $(1,0 \% \mathrm{p} / \mathrm{v})$ em tampão TAE $1 \mathrm{x}$ corado com brometo de etídio $(0,5 \mu \mathrm{g} / \mathrm{mL})$.

Primeiramente uma reação de PCR específica foi realizada contendo $1 \mu \mathrm{L}$ da amostra de DNA extraído (5-10ng) em 25 ciclos de amplificação com os oligonucleotídeos seletivos para os grupos Bacteria, Actinobacteria e Alfa e Beta Proteobacteria. As reações para cada grupo foram realizadas separadamente e em combinação com o iniciador 1492R. Para Alfa e Beta Proteobacteria, os oligonucleotídeos AlphaU e Beta-2 foram utilizados (GOMES et al., 2001). Os iniciadores seletivos para Actinobacteria (HEUER et al., 1997), Pseudomonas spp. (GARBEVA et al., 2004) e Paenibacillus spp. (DA SILVA et al., 2003) foram utilizados conforme descrito pela literatura.

O produto de amplificação dos grupos acessados foi utilizado como DNA molde na segunda reação de PCR para amplificação com os iniciadores para DGGE. Estas reações foram realizadas em volume de $50 \mu \mathrm{L}$ contendo aproximadamente $20 \mathrm{ng}$ de DNA molde e $400 \mathrm{nM}$ de cada primer universal U968-GC e R1378 utilizando 35 ciclos de amplificação com temperatura de anelamento de $55^{\circ} \mathrm{C}$. O produto da PCR foi avaliado por meio de eletroforese em gel de agarose $(1,0 \%$ p/v) em tampão TAE $1 x$, com posterior coloração em solução de brometo de etídeo $(1,0$ $\left.\mathrm{mg} / \mathrm{L}^{-1}\right)$ e visualização sob luz ultra-violeta.

O DGGE foi realizado conforme Heuer et al. (1997) com equipamento phorU2 system (Ingeny, Goes, Holanda). O produto de amplificação da segunda reação foi aplicado em gel de poliacrilamida $(6,0 \%$ p/v) em tampão TAE 1x. Este gel foi preparado com gradiente desnaturante variando de 45 a $65 \%$ (onde $100 \%$ de desnaturação significa concentração de $7 \mathrm{M}$ de uréia e $40 \%$ de formamida). Os géis foram submetidos a eletroforese vertical por $16 \mathrm{~h}$ a $100 \mathrm{~V}$ à temperatura de 
$60^{\circ} \mathrm{C}$ e posteriormente corados por $1 \mathrm{~h}$ com SYBR Gold (diluído 1:1.000) (Molecular Probes, Leiden, The Netherlands) e fotografado sob luz ultra-violeta.

\subsection{Análise estatística dos dados}

A análise dos dados de isolamento e atividade fisiológica foi conduzida usando o software SAS (Copyright ${ }^{\odot}$ 1989-1996 do SAS Institute, Cary, NC, USA) com a análise das variâncias $(P<$ 0.05). A contagen de bactérias foi transformadas usando $\log _{10}$ de $X+1$ antes das análises de variância. O Teste de Tukey foi usado para comparação das médias (STEEL e TORRIE, 1980).

Para análise dos géis de DGGE o programa GelCompar II (Applied Maths, Bélgica) foi utilizado para normalização, conversão e comparação das imagens em matrizes de presença/ausência e intensidade de bandas. A normalização e seleção de bandas, feita pelo programa, foram cuidadosamente avaliadas e correções manuais foram feitas quando necessárias. A matriz considerando presença ou ausência das bandas foi utilizada para análises posteriores. A correlação dos dados ambientais com a ocorrência das bandas foi determinada pela Análise de Redundância (RDA), realizada no software Canoco (Canoco 4.5, Biometris, Wageningen, Holanda) (TER BRAAK e SMILAUER, 2002). As bandas observadas nos géis de DGGE foram consideradas como espécies e o teste estatístico de permutação de Monte Carlo foi aplicado considerando 499 permutações aleatórias, permitindo avaliar a significância (valor $p$ ) dos fatores ambientais na distribuição de espécies das amostras. Como variáveis ambientais foram usadas às estações, os pontos e as profundidades amostradas. 


\section{RESULTADOS}

\subsection{Isolamento, análise do sedimento, caracterização molecular e identificação da comunidade bacteriana cultivável}

A densidade bacteriana foi analisada com relação ao logaritmo das unidades formadoras de colônias por grama de solo, obtidas dos isolamentos nas duas épocas amostradas. Foi observada diferença estatística $(P<0.05)$ entre as amostragens no inverno $\left(\log\right.$ de 6,85 UFC. $\left.\mathrm{g}^{-1}\right) \mathrm{e}$ verão (log de 6,22 UFC. $\mathrm{g}^{-1}$ ), mas esta diferença não foi observada entre as profundidades amostradas (Tabela 1). Foram coletadas aleatoriamete 238 bactérias sendo 159 colônias derivadas da coleta em 12/07/2005 (inverno) e 79 da coleta em 19/03/2006 (verão).

Tabela 1. Médias de contagem de colônias com letras diferentes calculadas estatisticamente pelo teste Tukey* $(5 \%)$.

\begin{tabular}{lc}
\hline Variável & Média $\left(\log \mathrm{UFC}^{-1}\right)$ \\
\hline Verão & $6.2200(\mathrm{~b})^{\star}$ \\
Inverno & $6.8580(\mathrm{a})^{\star}$ \\
Profundidade $0-10 \mathrm{~cm}$ & $6.5720(\mathrm{a})^{\star}$ \\
Profundidade $30-40 \mathrm{~cm}$ & $6.5060(\mathrm{a})^{\star}$ \\
\hline
\end{tabular}

As amostras foram caracterizadas físico-quimicamente em relação as suas texturas e disponibilidade de nutrientes e composição de matéria orgânica (Tabela 2) no Departamento de Solos, ESALQ/USP. 
Tabela 2. Análises físico-químicas das amostras coletadas do sedimento de manguezal. Os valores dos nutrientes $\mathrm{N}, \mathrm{P}, \mathrm{K}, \mathrm{Ca}$ e $\mathrm{Mg}$ estão expressos em g/Kg e Cu, Fe, Mn, Zn, Na em mg/Kg.

\begin{tabular}{|c|c|c|c|c|c|c|c|c|c|c|c|c|c|}
\hline Amostras & $\mathbf{N}$ & $\mathbf{P}$ & $\mathbf{K}$ & $\mathrm{Ca}$ & Mg & $\mathbf{C u}$ & Fe & Mn & Zn & $\mathrm{Na}$ & Areia & Lama & MO \\
\hline P1 (0-10cm) & 3,6 & 0,5 & 6,9 & 1,4 & 5,8 & 5,0 & 12500,0 & 157,5 & 85,0 & 149,5 & 20,5 & 79,5 & 93,0 \\
\hline P1 $(30-40 \mathrm{~cm})$ & 2,1 & 0,5 & 5,6 & 0,8 & 5,0 & 2,5 & 12950,0 & 230,0 & 117,5 & 115,0 & 26,4 & 73,6 & 67,0 \\
\hline$P 2(0-10 \mathrm{~cm})$ & 4,4 & 0,6 & 5,4 & 1,8 & 5,3 & 2,5 & 13950,0 & 167,5 & 65,0 & 80,5 & 35,6 & 64,4 & 99,0 \\
\hline P2 $(30-40 \mathrm{~cm})$ & 3,0 & 0,6 & 7,3 & 1,0 & 6,4 & 5,0 & 17,0 & 0,2 & 0,1 & 138,0 & 20,8 & 79,2 & 88,0 \\
\hline P3 (0-10cm) & 3,0 & 0,6 & 7,3 & 1,0 & 6,4 & 5,0 & 17000,0 & 232,5 & 77,5 & 138,0 & 94,9 & 5,1 & 29,0 \\
\hline P3 $(30-40 \mathrm{~cm})$ & 0,5 & 0,3 & 1,2 & 3,4 & 1,5 & 2,5 & 2950,0 & 85,0 & 42,5 & 46,6 & 84,7 & 15,3 & 38,0 \\
\hline P4 (0-10cm) & 1,2 & 0,3 & 1,2 & 0,6 & 1,4 & 20,0 & 4300,0 & 117,5 & 55,0 & 25,3 & 86,0 & 14,1 & 54,0 \\
\hline P4 $(30-40 \mathrm{~cm})$ & 0,0 & 0,3 & 0,0 & 0,1 & 0,2 & 2,5 & 350,0 & 20,0 & 27,5 & 17,3 & 97,1 & 2,9 & 9,0 \\
\hline P5 (0-10cm) & 1,0 & 0,3 & 0,1 & 0,5 & 0,7 & 10,0 & 2400,0 & 77,5 & 32,5 & 8,6 & 86,8 & 13,3 & 54,0 \\
\hline$P 5(30-40 \mathrm{~cm})$ & 0,0 & 0,3 & 0,0 & 0,1 & 0,2 & 2,5 & 1850,0 & 45,0 & 27,5 & 13,8 & 89,7 & 10,3 & 14,0 \\
\hline
\end{tabular}

A amplificação do 16S DNAr seguida da análise por ARDRA permitiu o agrupamento da diversidade bacteriana cultivável presente nas amostras avaliadas (Figura 2).

Com a amostragem realizada foi possível observar correlações entre a ocorrência dos ribotipos e as amostras de diferentes estações ou amostradas em diferentes profundidades do sedimento estudado. Dentre as amostras foi possível observar a predominância do ribotipo (A) compreendendo linhagens pertencentes à ordem Vibrionales em maior densidade na estação do inverno na profundidade de $30-40 \mathrm{~cm}$. Os ribotipos $\mathrm{B}$ e D estiveram presentes em todas as amostras analisadas sendo das ordens Actinomicetales e Bacillales grupos constantes no ambiente estudado. O ribotipo $\mathrm{C}$, também de Bacillales, foi observado apenas na amostragem de inverno. Os ribotipos H, I e J (ordem Actinomicetales) foram isolados apenas no verão, enquanto os ribotipos E, F e G apresentaram uma densidade menor no inverno (Figura 3).

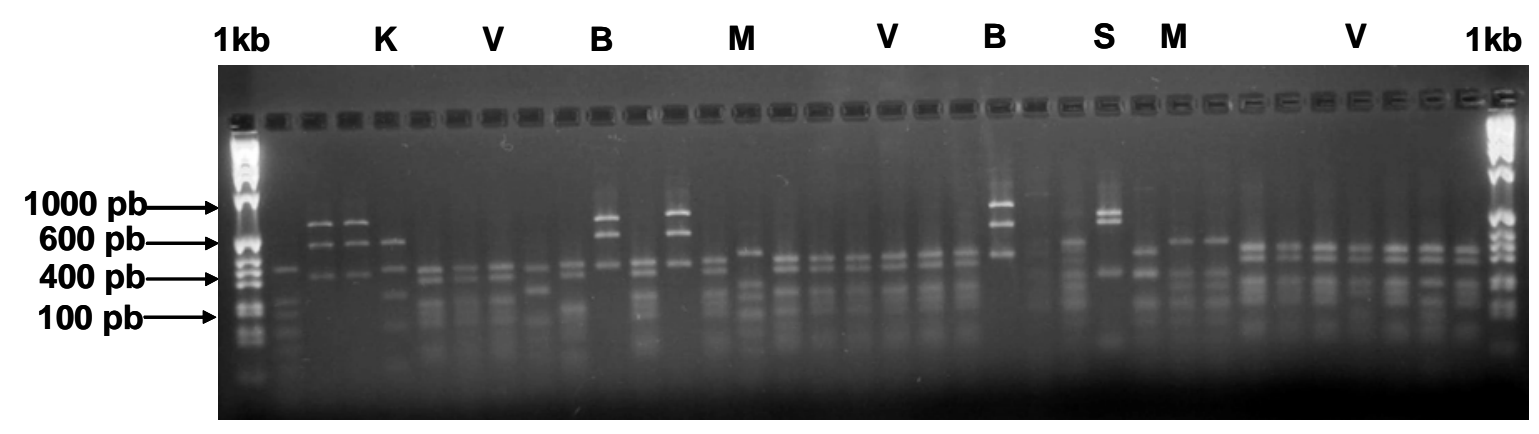

Figura 2. Gel de agarose com os perfis de bandas dos principais grupos obtidos pela digestão com a enzima de restrição HaeIII onde V-Vibrio spp., M-Microbacterium spp., B-Bacillus spp., K-Kurthia spp. e S-Staphylococcus spp., $1 \mathrm{~Kb}$ - marcador de $1000 \mathrm{pb}$ e as setas indicam as bandas e seus pares de bases respectivos. 


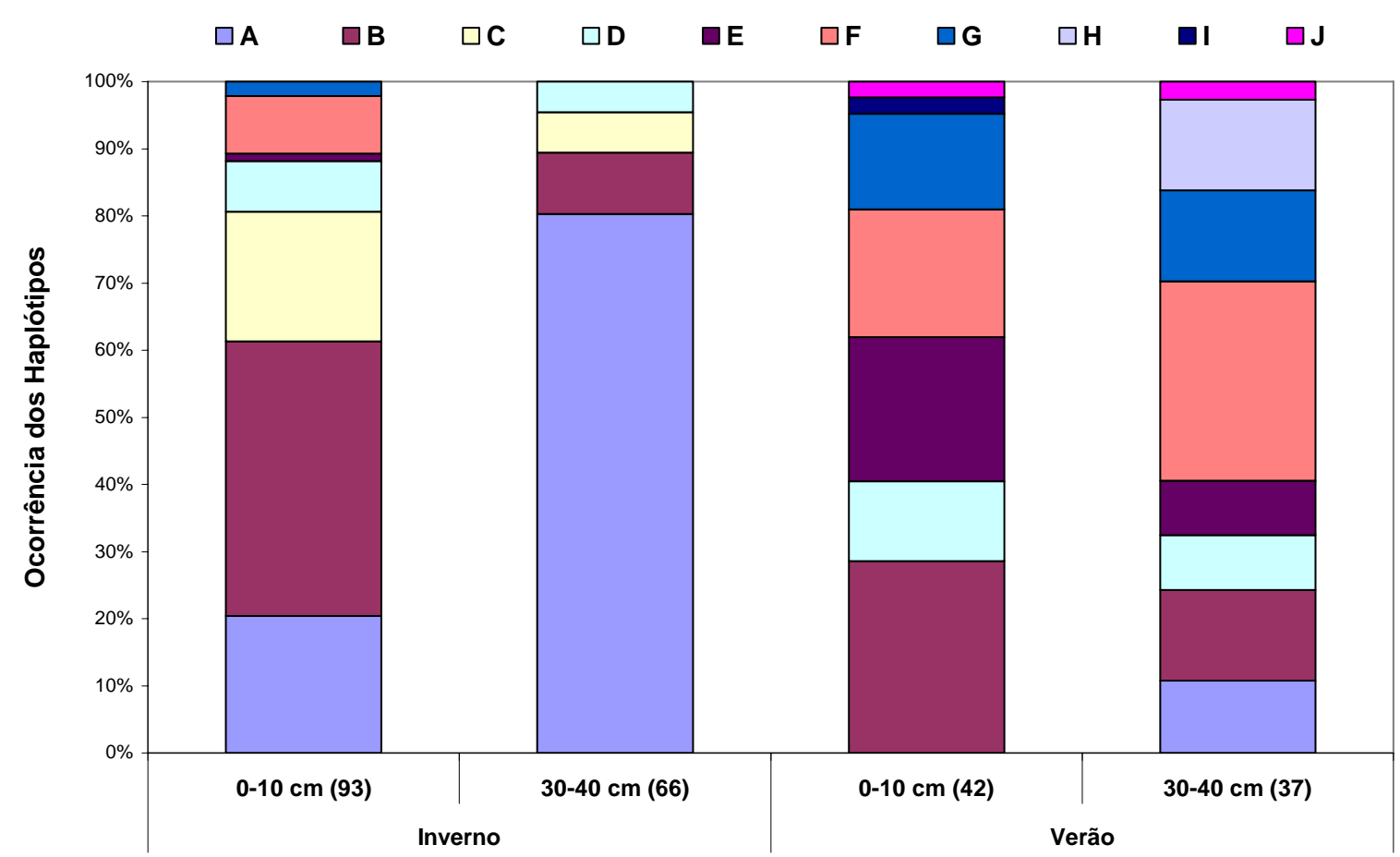

Figura 3. Gráfico comparativo com a ocorrência de ribotipos bacterianos nas estações inverno e verão e nas diferentes profundidades amostradas. A-Vibrio spp., Listonella spp., Aeromonas spp., B Microbacterium spp., Brevibacterium spp., Dermabacter spp.; C - Bacillus spp., D - Staphylococcus spp.; E - Paenibacillus spp.; F - Kurthia spp., G - Nesteronkonia spp.; H - Kytococcus spp.; I - Kocuria spp.; F Rothia spp. O número ao lado da profundidade representa a quantidade de isolados bacterianos.

Os fragmentos clivados com a enzima de restrição HaeIII geraram 10 diferentes ribotipos, dos quais foram selecionados isolados para identificação por cromatografia gasosa de ácidos graxos (MIDI-FAME), mostrando que a comunidade bacteriana é composta por bactérias dos gêneros Vibrio, Listonella, Aeromonas, Microbacterium, Dermabacter, Brevibacterium, Paenibacillus, Staphylococcus, Kurthia, Bacillus, Nesteronkonia, Kytococcus, Kocuri e Rothia (Tabela 3). 
Tabela 3. Identificação das bactérias obtidas dos isolamentos a partir de amostras de sedimentos do manguezal, identificadas por perfil de ácidos graxos (FAME).

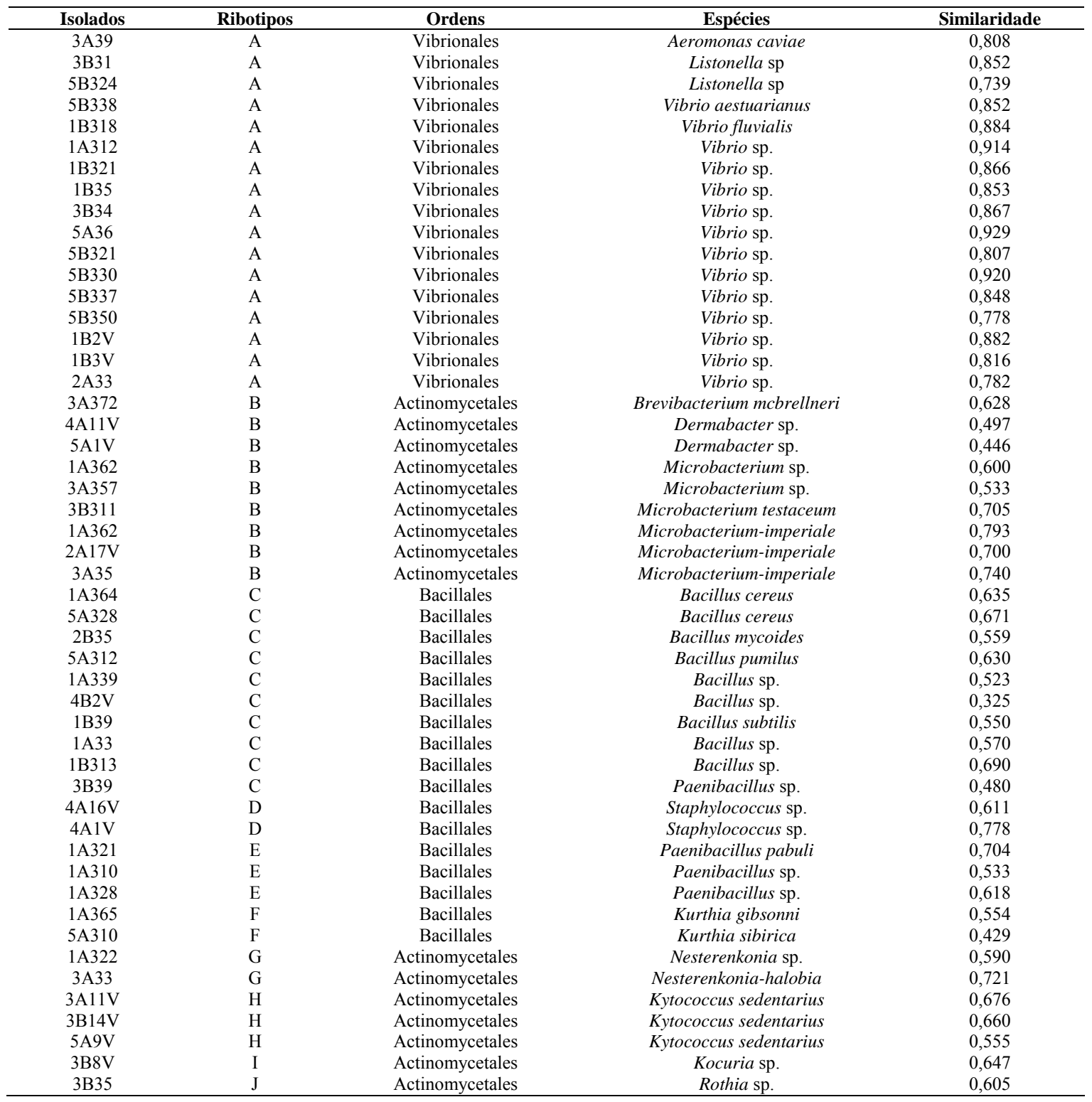

\subsection{Avaliação do Potencial Biotecnológico na Produção de Enzimas pelas Bactérias Isoladas do Sedimento de Manguezal}

A avaliação do perfil de produção de enzimas das linhagens bacterianas isoladas do sedimento de manguezal foi realizada por meio da análise das atividades amilolítica, proteolítica, lípolítica e esterásica destes isolados (Tabela 3). A produção destas enzimas foram avaliadas também em relação aos pontos amostrados e as profundidades avaliadas (Figura 4). Quando se analisa a distribuição do perfil enzimático considerando as profundidades e os pontos amostrados, foi observada uma variação significativa nas atividades enzimáticas. Primeiramente, o ponto 4 apresentou uma maior freqüência de isolados produtores de enzimas protelíticas, amilolíticas e 
esterásicas. Neste ponto, estas atividades foram mais freqüentes em isolados obtidos das amostras de maior profundidade $(30-40 \mathrm{~cm})$. A atividade amilolítica do ponto 5 foi alta, comparável a encontrada no ponto 4. A única atividade enzimática que não foi maior no ponto 4 foi a atividade lipolítica, que foi mais freqüente na comunidade bacteriana no ponto $2 \mathrm{e}$ em camadas mais superficiais do sedimento $(0-10 \mathrm{~cm})$.

\section{(a)}

(b)

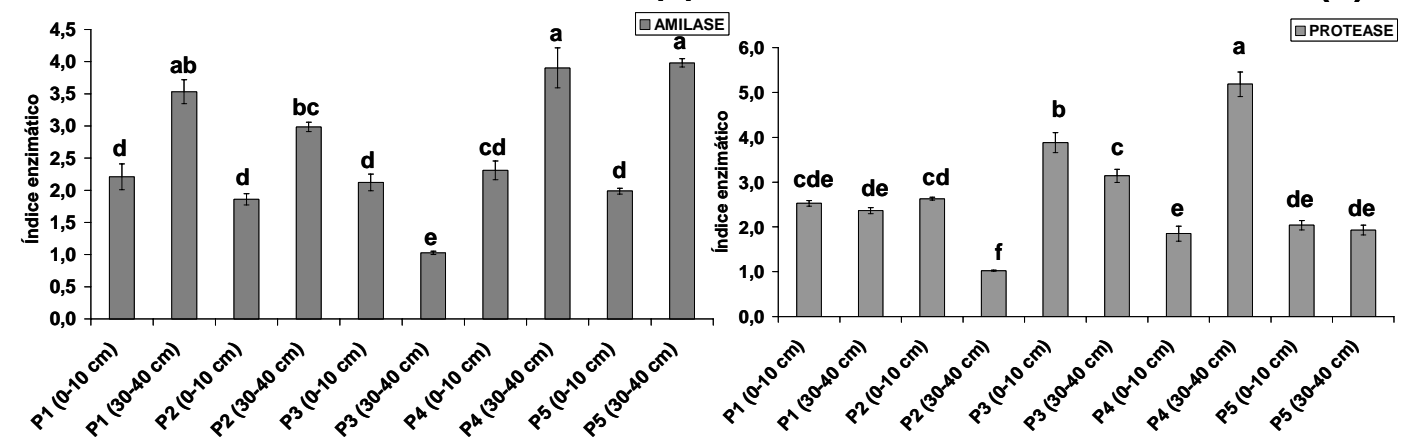

(c)

(d)

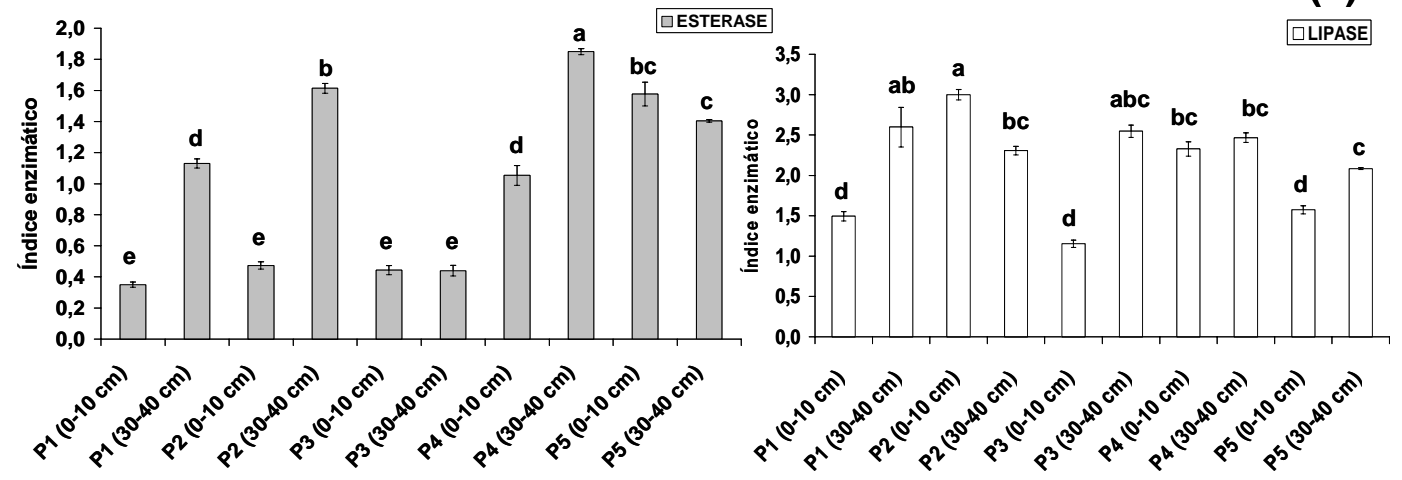

Figura 4. Atividades enzimáticas dos isolados testados correlacionando os pontos e a profundidade amostrada. Amilase (a), Protease (b), Esterase (c) e Lípase (d). As barras representam as medidas do halo menos a das colônias por isolado $(n=3)$ e as letras diferentes entre barras da mesma enzima mostram diferença estatística significativa pelo teste de Tukey $(p<0,05)$.

Desconsiderando os pontos, e comparando apenas as profundidades amostradas, é possível verificar que na profundidade de $0-10 \mathrm{~cm}$ a atividade das enzimas lipase e esterase é maior, enquanto que na profundidade de $30-40 \mathrm{~cm}$ uma maior atividade de amilases é verificada (Figura 5). Em análise similar, não foi observada diferença significativa entre as profundidades para a frequência de bactérias proteolíticas. 


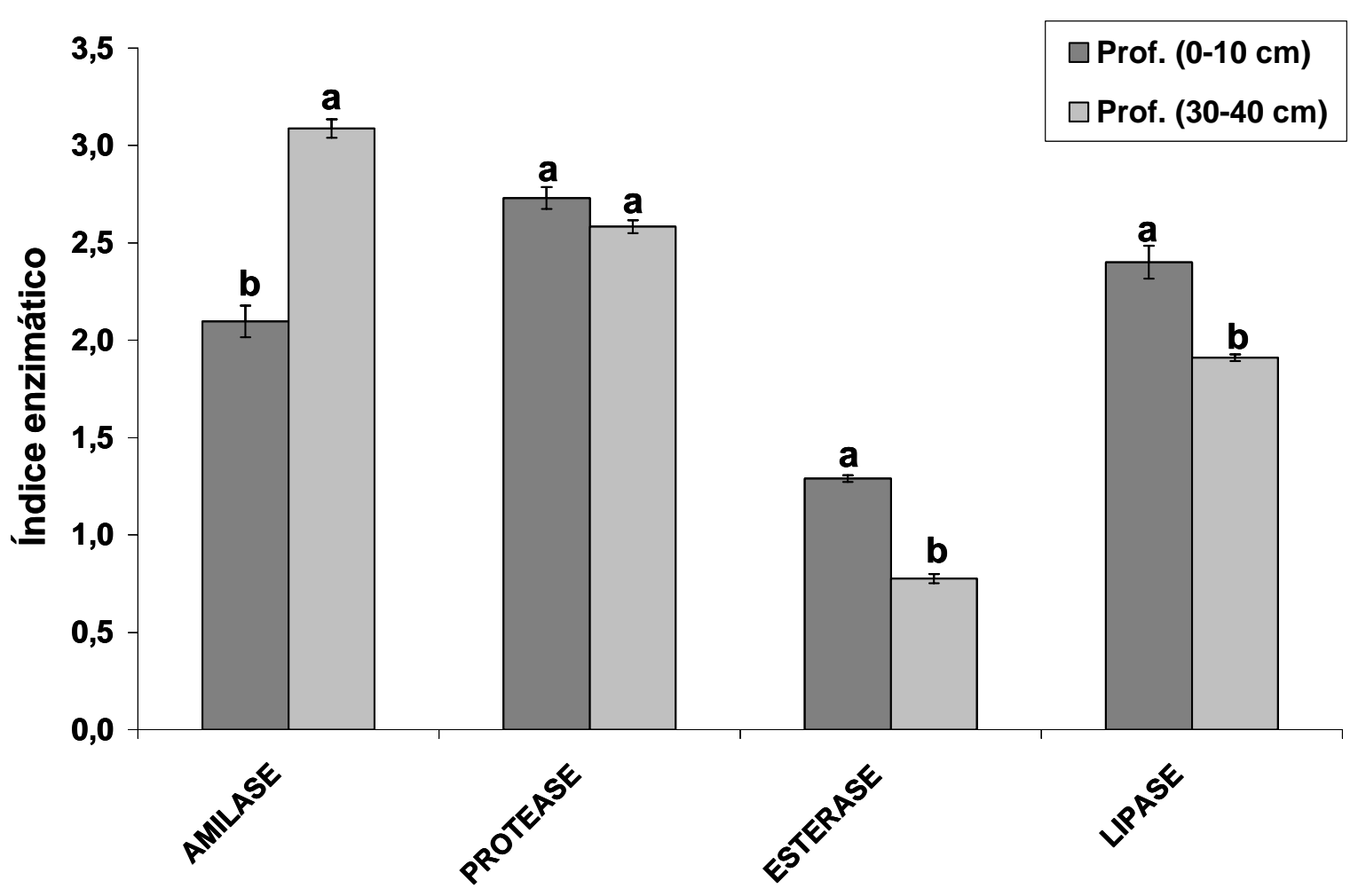

Figura 5. Atividades enzimáticas dos isolados testados correlacionando as profundidades amostradas. As barras representam as medidas do halo menos a das colônias por isolado $(n=3)$ e as diferentes letras mostram diferença estatística significativa pelo teste de Tukey $(p<0,05)$.

Considerando a ocorrência da produção de enzimas para cada ribotipos observados na classificação genotípica por ARDRA, foi observado que além de ser o grupo mais freqüente, os isolados de Vibrionales (ribotipo A) foram os maiores produtores de enzimas. Os representantes de Actinomycetales e Bacilalles compuseram outros importantes grupos bacterianos produtores de enzimas no ambiente de manguezal. Comparando estes grupos para a produção das diversas enzimas avaliadas, é possível sugerir que a produção de amilases e proteases é mais intensa em isolados de Vibrionales, enquanto que as demais enzimas podem ser produzidas igualmente pelos três grupos identificados como funcionais. 
Tabela 4. Atividades enzimáticas extracelulares dos isolados dos principais grupos taxonômicos produtores de enzimas obtidos de sedimento do manguezal localizado na Ilha do Cardoso. Os dados mostram a média dos halos de degradação.

\begin{tabular}{|c|c|c|c|c|c|}
\hline Ordem & Linhagens & Amilase & Protease & Esterase & Lipase \\
\hline \multirow{30}{*}{ Vibrionales } & 1A311 & NT & $4,24 \pm 0,12^{b}$ & NT & NT \\
\hline & $1 \mathrm{~B} 32$ & $5,13 \pm 0,07^{\text {abcde }}$ & NT & $2,97 \pm 0,28^{a b}$ & $3,27 \pm 0,08^{b c}$ \\
\hline & $1 \mathrm{~B} 35$ & $6,44 \pm 0,75^{a b c}$ & $2,31 \pm 0,22^{\mathrm{cd}}$ & NT & NT \\
\hline & $2 \mathrm{~A} 33$ & NT & $8,96 \pm 0,77^{a}$ & $2,28 \pm 0,14^{\text {cdef }}$ & $2,74 \pm 0,11^{\text {bcdefg }}$ \\
\hline & 2B324 & $1,78 \pm 0,06^{\mathrm{fg}}$ & - & $2,53 \pm 0,27^{\text {abcd }}$ & $4,80 \pm 0,11^{a}$ \\
\hline & $2 B 326$ & $5,46 \pm 0,30^{\mathrm{abcd}}$ & - & $1,57 \pm 0,26^{\mathrm{ijk}}$ & $1,91 \pm 0,08^{\text {hijk }}$ \\
\hline & 2B327 & - & $4,36 \pm 0,22^{b}$ & $1,89 \pm 0,11^{\text {efghij }}$ & $2,31 \pm 0,09^{\text {efghijk }}$ \\
\hline & 2B331 & $6,65 \pm 1,04^{a b}$ & NT & $2,24 \pm 0,46^{\text {cdefg }}$ & $2,51 \pm 0,14^{\text {cdefghi }}$ \\
\hline & $2 \mathrm{~B} 38$ & NT & - & $2,40 \pm 0,10^{\text {bcde }}$ & $2,00 \pm 0,23^{\text {ghijlk }}$ \\
\hline & $3 \mathrm{~B} 33$ & 11 & $9,48 \pm 0,64^{a}$ & $2,19 \pm 0,17^{\text {cdefgh }}$ & $2,33 \pm 0,16^{\text {efghijk }}$ \\
\hline & $4 \mathrm{~A} 312$ & NT & $3,35 \pm 0,53^{b c}$ & $2,43 \pm 0,14^{\text {bcde }}$ & $3,15 \pm 0,22^{\mathrm{bcd}}$ \\
\hline & $4 \mathrm{~A} 313$ & $6,13 \pm 0,70^{a b c d}$ & NT & - & $1,91 \pm 0,12^{\text {hijlk }}$ \\
\hline & $4 \mathrm{~A} 35$ & $5,00 \pm 0,58^{\text {abcde }}$ & NT & $1,58 \pm 0,11^{\mathrm{hijk}}$ & $2,79 \pm 0,18^{\text {bcdef }}$ \\
\hline & 4B312 & $3,42 \pm 0,48^{\text {def }}$ & $3,35 \pm 0,53^{b c}$ & $2,43 \pm 0,14^{\text {bcde }}$ & $3,33 \pm 0,00^{b}$ \\
\hline & 4B314 & $7,26 \pm 0,9^{a}$ & NT & $1,08 \pm 0,12^{\mathrm{jk}}$ & $1,83 \pm 0,04^{\mathrm{ij} / \mathrm{k}}$ \\
\hline & $4 \mathrm{~B} 37$ & $4,17 \pm 0,48^{\text {bcdef }}$ & NT & $1,72 \pm 0,06^{\text {fghij }}$ & $2,87 \pm 0,07^{\text {bcde }}$ \\
\hline & 4B38 & $6,22 \pm 0,95^{a b c}$ & $2,5 \pm 0,28^{\mathrm{cd}}$ & $1,67 \pm 0,00^{\text {ghijk }}$ & $2,40 \pm 0,05^{\text {defghijk }}$ \\
\hline & 4B39 & - & $7,93 \pm 0,86^{a}$ & $1,89 \pm 0,00^{\text {efghij }}$ & $1,67 \pm 0,00^{\mathrm{jlk}}$ \\
\hline & $5 \mathrm{~A} 32$ & $4,86 \pm 0,22^{\mathrm{abcde}}$ & $2,06 \pm 0,48^{\mathrm{cd}}$ & $2,16 \pm 0,08^{\text {efghi }}$ & $2,71 \pm 0,35^{\text {bcdefgh }}$ \\
\hline & $5 A 36$ & NT & - & $2,52 \pm 0,29^{\text {bcd }}$ & $2,5 \pm 0,00^{\text {cdefghi }}$ \\
\hline & $5 B 31$ & $4,7 \pm 0,22^{\text {abcde }}$ & NT & $2,16 \pm 0,18^{\text {efghi }}$ & $3,38 \pm 0,09^{b}$ \\
\hline & $5 B 312$ & $6,16 \pm 0,71^{a b c}$ & - & NT & NT \\
\hline & $5 B 313$ & $5,40 \pm 0,00^{\text {abcde }}$ & - & $3,14 \pm 0,14^{a}$ & $2,46 \pm 0,18^{\text {cdefghij }}$ \\
\hline & $5 B 323$ & $6,24 \pm 0,88^{\mathrm{abc}}$ & NT & $1,66 \pm 0,11^{\text {ghijk }}$ & $2,05 \pm 0,10^{\text {fghijlk }}$ \\
\hline & $5 B 328$ & $5,92 \pm 0,38^{a b c d}$ & $3,03 \pm 0,25^{\mathrm{bcd}}$ & $\begin{array}{r}1,00-0,+1 \\
-\end{array}$ & \\
\hline & $5 B 329$ & NT & $8,21 \pm 0,74^{a}$ & $2,00 \pm 0,08^{\text {defghij }}$ & $1,61 \pm 0,04^{\mathrm{kl}}$ \\
\hline & $5 B 33$ & $4,44 \pm 0,38^{\text {bcdef }}$ & NT & $2,16 \pm 0,08^{\text {efghi }}$ & $2,71 \pm 0,20^{\text {bcdefgh }}$ \\
\hline & $5 B 336$ & NT & NT & $2,78 \pm 0,19^{a b c}$ & $2,33 \pm 0,16^{\text {efghijk }}$ \\
\hline & $5 \mathrm{~B} 337$ & $3,77 \pm 0,37^{\text {cdef }}$ & NT & $2,50 \pm 0,00^{\text {bcde }}$ & $2,42 \pm 0,07^{\text {defghijk }}$ \\
\hline & $5 B 340$ & $6,60 \pm 0,40^{a b}$ & NT & - & $1,86 \pm 0,02^{\mathrm{ijlk}}$ \\
\hline \multirow{24}{*}{ Actinomicetales } & 1A358 & $3,35 \pm 0,34^{a b}$ & - & - & \\
\hline & $1 \mathrm{~A} 373$ & - & - & - & $4,07 \pm 0,18^{a b}$ \\
\hline & 1B18V & $2,80 \pm 0,14^{\text {bcdef }}$ & - & - & $4,25 \pm 1,25^{a b}$ \\
\hline & $1 \mathrm{~B} 5 \mathrm{~V}$ & $2,28 \pm 0,25^{\text {efgh }}$ & $2,43 \pm 0,20^{\text {ef }}$ & $2,77 \pm 0,15^{b}$ & $2,29 \pm 0,17^{\text {cde }}$ \\
\hline & $1 \mathrm{~B} 7 \mathrm{~V}$ & $3,25 \pm 0,05^{\mathrm{abc}}$ & - & - & $4,00 \pm 0,00^{a b}$ \\
\hline & $2 \mathrm{~A} 13 \mathrm{~V}$ & $3,26 \pm 0,08^{a b c}$ & $3,71 \pm 0,29^{\text {abcd }}$ & - & $4,83 \pm 0,16^{a}$ \\
\hline & $2 \mathrm{~A} 1 \mathrm{~V}$ & - & $3,08 \pm 0,14^{\text {abcde }}$ & - & \\
\hline & $2 \mathrm{~A} 21 \mathrm{~V}$ & - & $3,71 \pm 0,29^{\mathrm{abcd}}$ & - & $3,95 \pm 0,12^{a b}$ \\
\hline & $2 \mathrm{~A} 23 \mathrm{~V}$ & $3,22 \pm 0,10^{a b c d}$ & - & - & $1,94 \pm 0,22^{\text {cde }}$ \\
\hline & $2 \mathrm{~A} 324$ & $3,05 \pm 0,05^{\text {abcde }}$ & - & - & $3,83 \pm 0,23^{a b}$ \\
\hline & $2 \mathrm{~A} 370$ & $3,20 \pm 0,14^{a b c d}$ & - & - & $4,25 \pm 0,25^{a b}$ \\
\hline & $3 \mathrm{~A} 1 \mathrm{~V}$ & 0 & $3,23 \pm 0,22^{\text {abcde }}$ & - & - \\
\hline & 3A35 & $2,28 \pm 0,14^{\text {efgh }}$ & $3,00 \pm 0,09^{\text {bcde }}$ & - & - \\
\hline & $3 \mathrm{~B} 2 \mathrm{~V}$ & $1,92 \pm 0,04^{\mathrm{gh}}$ & $4,02 \pm 0,18^{a b}$ & - & - \\
\hline & 3B311 & $3,25 \pm 0,09^{a b c}$ & - & - & $3,08 \pm 0,08^{\mathrm{bcd}}$ \\
\hline & 3B320 & - & - & - & $3,84 \pm 0,27^{a b}$ \\
\hline & 4A11V & - & $4,28 \pm 0,46^{a}$ & $3,37 \pm 0,34^{a}$ & - \\
\hline & $4 A 353$ & $2,79 \pm 0,18^{\text {bcdef }}$ & - & - & $4,22 \pm 0,25^{a b}$ \\
\hline & $5 A 2 V$ & - & $3,71 \pm 0,41^{\mathrm{abcd}}$ & $3,02 \pm 0,23^{a b}$ & - \\
\hline & $5 \mathrm{~A} 4 \mathrm{~V}$ & $3,64 \pm 0,14^{a}$ & - & - & - \\
\hline & $5 \mathrm{~A} 5 \mathrm{~V}$ & - & $3,79 \pm 0,12^{a b c}$ & - & - \\
\hline & $5 B 2 V$ & - & $3,28 \pm 0,27^{\text {abcde }}$ & - & - \\
\hline & $5 \mathrm{~B} 3 \mathrm{~V}$ & $2,44 \pm 0,23^{\operatorname{defg}}$ & $4,07 \pm 0,34^{a b}$ & - & - \\
\hline & $5 \mathrm{~B} 5 \mathrm{~V}$ & $3,11 \pm 0,35^{\text {abcd }}$ & - & - & $3,30 \pm 0,12^{b c}$ \\
\hline \multirow{12}{*}{ Bacillales } & $1 \mathrm{~A} 33$ & $5,06 \pm 0,33^{a}$ & $4,67 \pm 0,18^{a b}$ & $4,67 \pm 0,18^{\mathrm{ab}}$ & $1,48 \pm 0,05^{\mathrm{d}}$ \\
\hline & 1A337 & $2,86 \pm 0,33^{a b}$ & $5,53 \pm 0,36^{a}$ & - & $1,+6-0,00$ \\
\hline & $1 \mathrm{A339}$ & $3,75 \pm 0,66^{\mathrm{ab}}$ & $3,74 \pm 0,06^{b c}$ & $1,16 \pm 0,03^{d}$ & $3,86 \pm 0,18^{a}$ \\
\hline & 1A364 & & - & - & $0,00 \pm 0,00^{\mathrm{e}}$ \\
\hline & 1B39 & $4,83 \pm 0,73^{a}$ & $5,36 \pm 0,13^{a}$ & $1,18 \pm 0,23^{\mathrm{cd}}$ & $1,73 \pm 0,24^{\mathrm{cd}}$ \\
\hline & $2 \mathrm{~A} 349$ & $3,62 \pm 0,53^{\mathrm{ab}}$ & $4,04 \pm 0,35^{a b c}$ & $1,50 \pm 0,17^{\mathrm{bcd}}$ & $1,47 \pm 0,14^{d}$ \\
\hline & $2 \mathrm{~B} 35$ & $3,20 \pm 0,33^{a b}$ & $2,84 \pm 0,04^{\mathrm{C}}$ & $1,15 \pm 0,03^{d}$ & $1,97 \pm 0,03^{\mathrm{cd}}$ \\
\hline & 3A312 & $4,09 \pm 0,86^{\mathrm{ab}}$ & $5,25 \pm 0,36^{a b}$ & $1,32 \pm 0,08^{\mathrm{cd}}$ & $1,45 \pm 0,13^{d}$ \\
\hline & $4 \mathrm{~B} 2 \mathrm{~V}$ & $2,33 \pm 0,59^{b}$ & $5,11 \pm 0,33^{a b}$ & $2,34 \pm 0,08^{a}$ & $2,68 \pm 0,20^{b}$ \\
\hline & 5A1V & - & - & - & \\
\hline & $5 A 312$ & - & $4,63 \pm 0,67^{a b}$ & $1,80 \pm 0,04^{\mathrm{abc}}$ & $1,33 \pm 0,01^{d}$ \\
\hline & $5 B 312$ & - & - & $1,97 \pm 0,04^{a b}$ & $2,33 \pm 0,16^{b c}$ \\
\hline
\end{tabular}




\subsection{Diversidade da Comunidade Bacteriana por meio de Técnica Independente de Cultivo}

A análise de DGGE permitiu avaliar a diversidade bacteriana do sedimento de manguezal independentemente do cultivo, relacionando as variáveis ambientais com os diferentes grupos bacterianos estudados. Considerando as similaridades nos perfis de DGGE obtidos foram construídos dendrogramas para cada um dos grupos bacterianos acessados; Bactéria, Alfaproteobacteria, Betaproteobacteria, Actinobacteria, Pseudomonas e Paenibacillus.

A análise do dendograma do DGGE contendo o perfil para o domínio Bactéria apresentou similaridade entre as estações do ano e revelou diferenças entre comunidades amostradas em diferentes profundidades (Figura 6). Adicionalmente, foi observada a separação das amostras coletadas no ponto 5 .

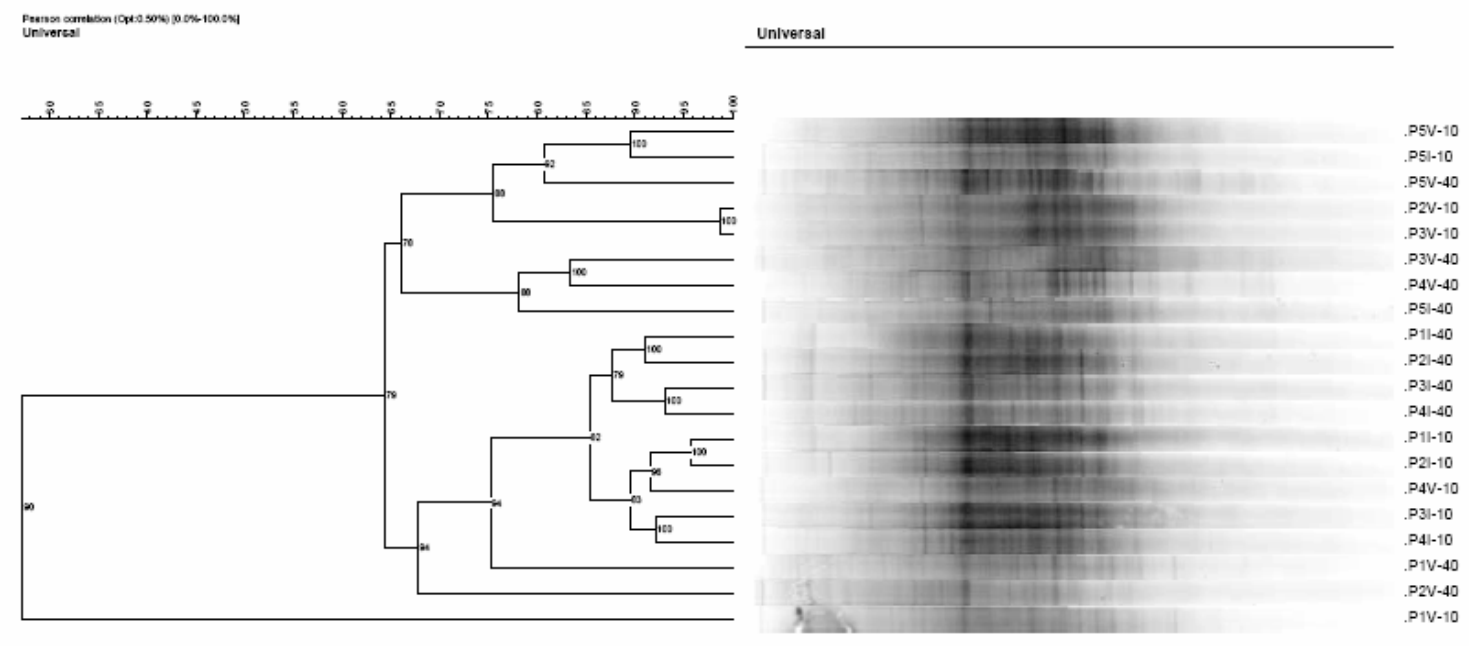

Figura 6. Correlação das amostras com base nos perfis de DGGE obtido com iniciadores para o domínio Bacteria. As amostras foram coletadas em 5 pontos (P1 a P5), em duas épocas do ano, verão (V) e inverno (I), em duas diferentes profundidades de sedimento $(0-10$ e $30-40 \mathrm{~cm})$. O agrupamento foi realizado por correlação de Pearson das curvas densitométricas das amostras, e o dendrograma foi determinado por UPGMA. Os valores nos ramos indicam a correlação cofenética do agrupamento das amostras.

Com relação ao DGGE do grupo Alfaproteobacteria o perfil de banda gerado demonstrou alta similaridade entre os pontos 1 e 4 e distanciamento das amostras devido à sazonalidade e às profundidades amostradas (Figura 7a). O DGGE utilizando oligonucleotídeos para acessar a população bacteriana formada pela classe Betaproteobacteria revelou a formação de dois grandes agrupamentos, que separam as épocas do ano em que foram realizadas as amostragens. Adicionalmente, as amostras do ponto 5 foram também diferenciadas das demais (Figura 7b). O grupo de Actinobacteria mostrou similaridade entre os pontos, estações e profundidades (Figura $7 \mathrm{c})$. 


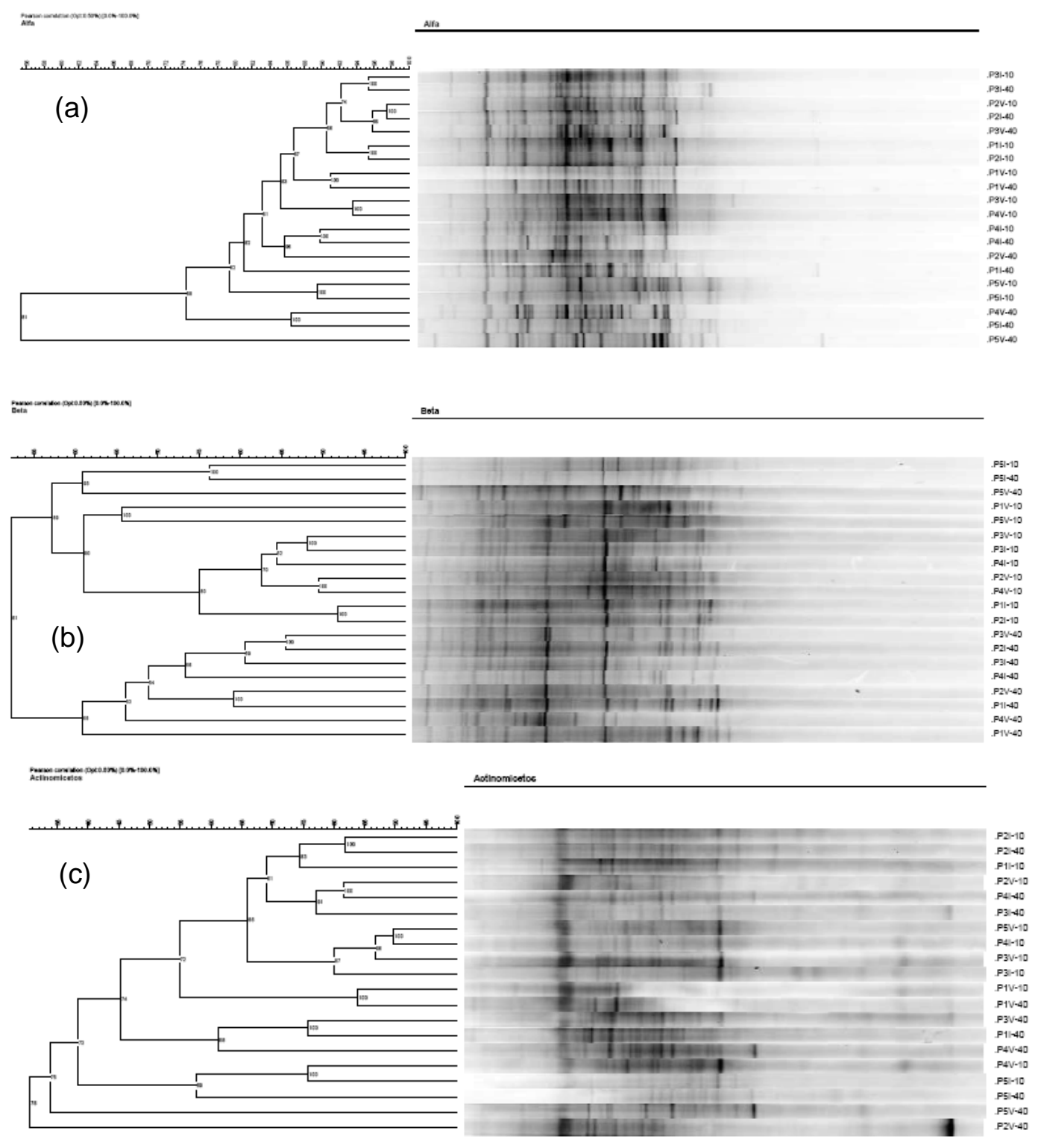

Figura 7. Correlação das amostras com base nos perfis de DGGE obtido com iniciadores para os grupos Alfaproteobacteria (a), Betaproteobacteria (b) e Actinobacteria (c). As amostras foram coletadas em 5 pontos (P1 a P5), em duas épocas do ano, verão (V) e inverno (I), em duas diferentes profundidades de sedimento $(0-10$ e $30-40 \mathrm{~cm})$. O agrupamento foi realizado por correlação de Pearson das curvas densitométricas das amostras, e o dendrograma foi determinado por UPGMA. Os valores nos ramos indicam a correlação cofenética do agrupamento das amostras.

Acessando de forma mais específica as comunidades de Pseudomonas spp. e Paenibacillus spp. foi possível verificar a composição das comunidades referentes a estes gêneros bacterianos de maneira bastante variável, independentemente dos fatores ambientais considerados na amostragem. (Figura 8). 

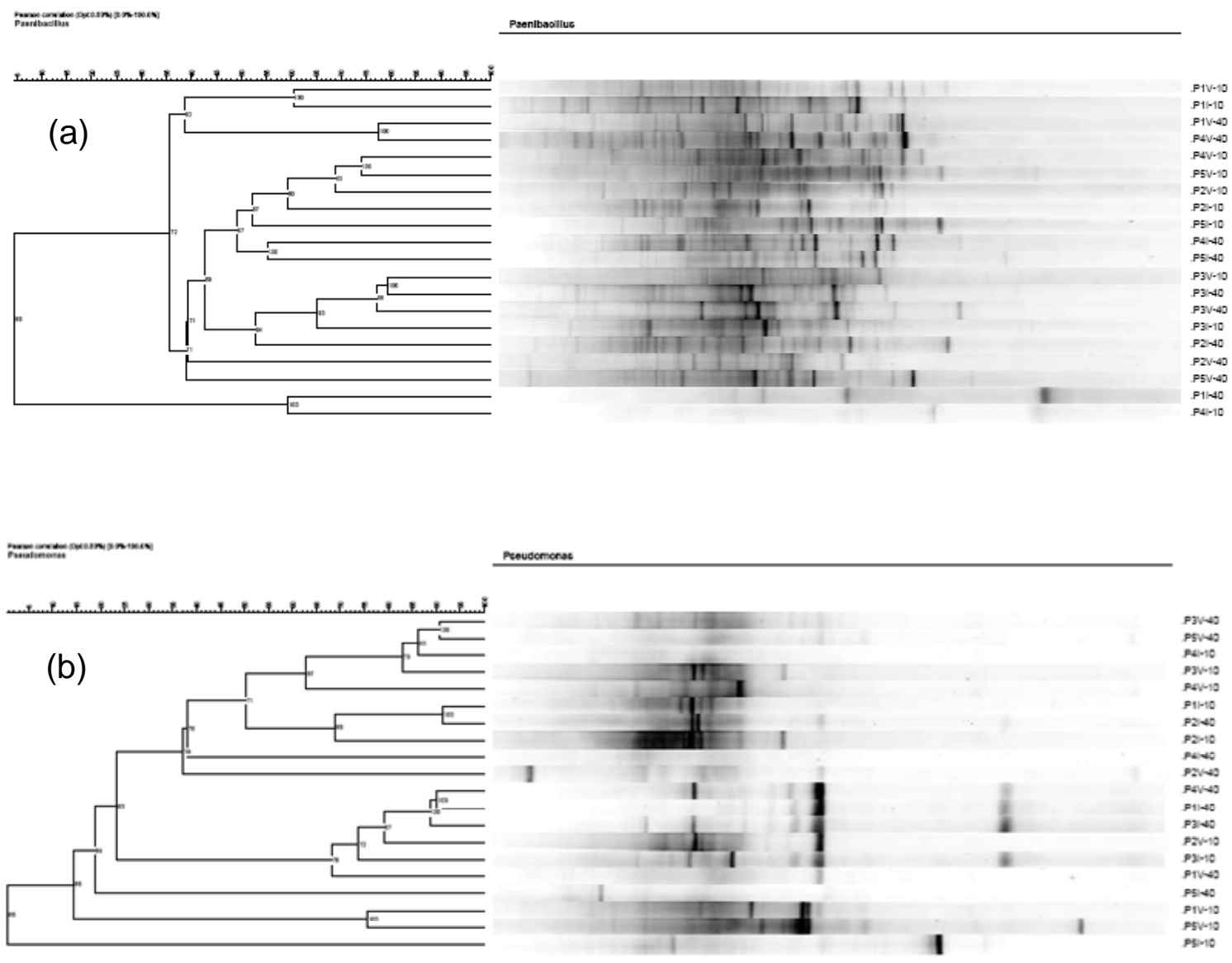

Figura 8. Correlação das amostras com base nos perfis de DGGE obtido com iniciadores para os gêneros Paenibacillus (a) e Pseudomonas (b). As amostras foram coletadas em 5 pontos (P1 a P5), em duas épocas do ano, verão (V) e inverno (I), em duas diferentes profundidades de sedimento $(0-10$ e 30-40 cm). O agrupamento foi realizado por correlação de Pearson das curvas densitométricas das amostras, e o dendrograma foi determinado por UPGMA. Os valores nos ramos indicam a correlação cofenética do agrupamento das amostras.

\subsection{Análise dos Fatores Ambientais Determinantes da Composição da Comunidade Bacteriana do Manguezal}

Os perfis de DGGE permitiram a construção de matrizes considerando a presença e a intensidade relativa de cada uma das bandas, que foram utilizadas como a ocorrência de espécies nas amostras. Estes perfis de DGGE foram correlacionados com o conjunto de características ambientais relacionadas às amostras de manguezal utilizadas neste trabalho. As variáveis: pontos amostrados, profundidade e sazonalidade serviram de base para a criação dos principais fatores analisados na ordenação (Figuras 9, 10 e 11). O resultado da análise (RDA) permitiu acessar os fatores que apresentam maior ou menor interferência na determinação dos perfis de DGGE e conseqüentemente na composição da comunidade bacteriana. 
Analisando os perfis de DGGE obtidos com oligonucleotídeos universais para o domínio bactéria foi possível apenas verificar como fatores significativamente $(p<0,05)$ determinantes da comunidade bacteriana a profundidade amostrada e o ponto 5 (Figura 9).

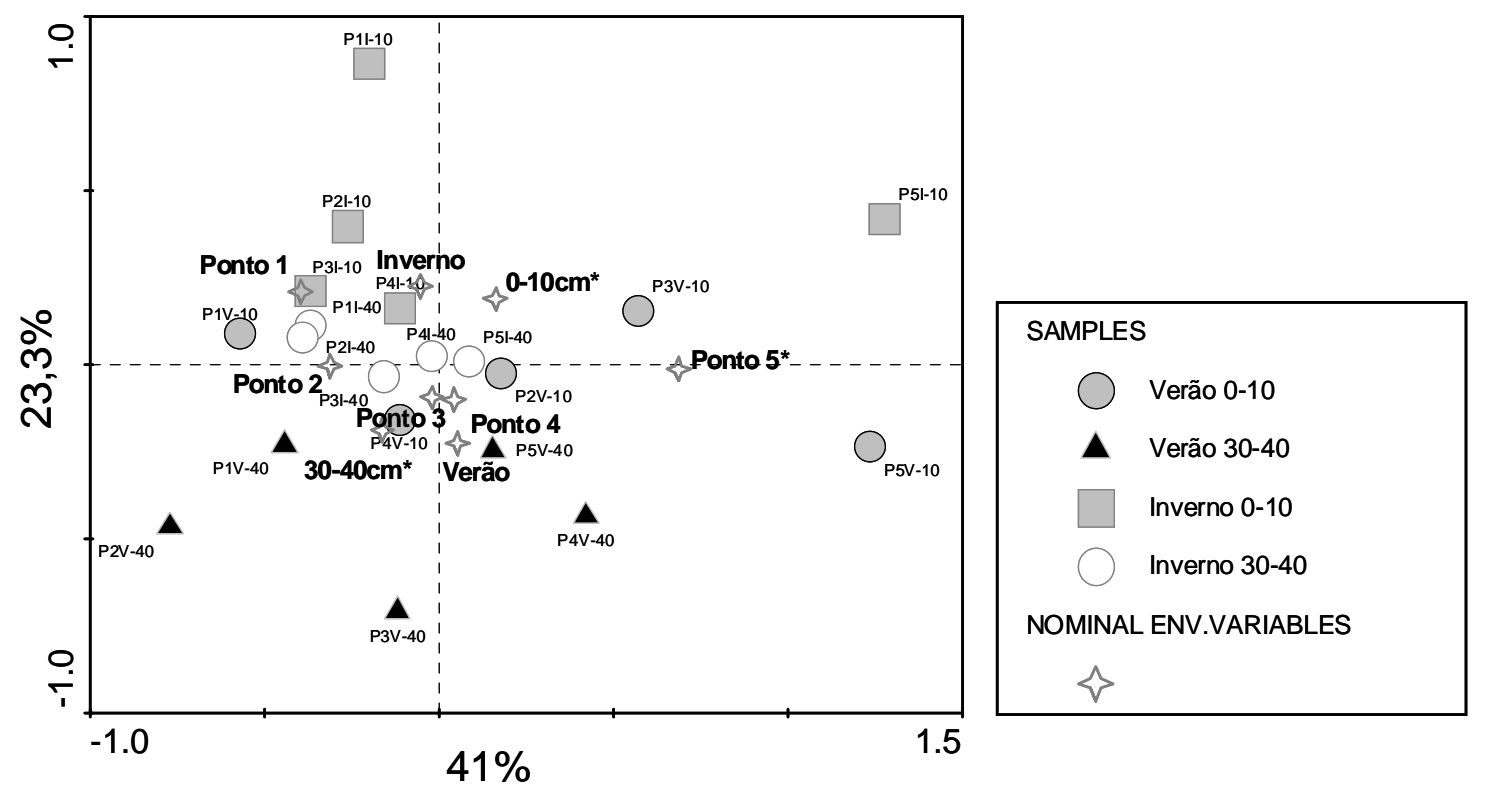

Figura 9. Agrupamento das amostras de sedimento de manguezal pela análise de Redundância (RDA) e relação com fatores ambientais determinantes da comunidade bacteriana total (Domínio Bacteria) obtido por DGGE. Todas as variáveis ambientais são mostradas, no entanto apenas as marcadas com asterisco foram determinantes na composição das comunidades bacterianas $(p<0.05)$ de acordo com o teste de permutação de Monte Carlo. Os valores indicam a porcentagem da variância dos dados explicada em cada um dos eixos.

O grupo das Alfa e Betaproteobacterias mostraram diferenças significativas nas variáveis profundidades $(p=0.01 ; 0.05)$ e época do ano $(p=0.05 ; 0.04)$, respectivamente (Figura 10). A análise de redundância para o grupo de Actinobactérias também mostrou significância nas profundidades $(p=0.002)$, outros fatores que mostraram influenciar a composição desta comunidade foram o ponto 1 ( $p=0.002)$ e o ponto $5(p=0.014)$. 


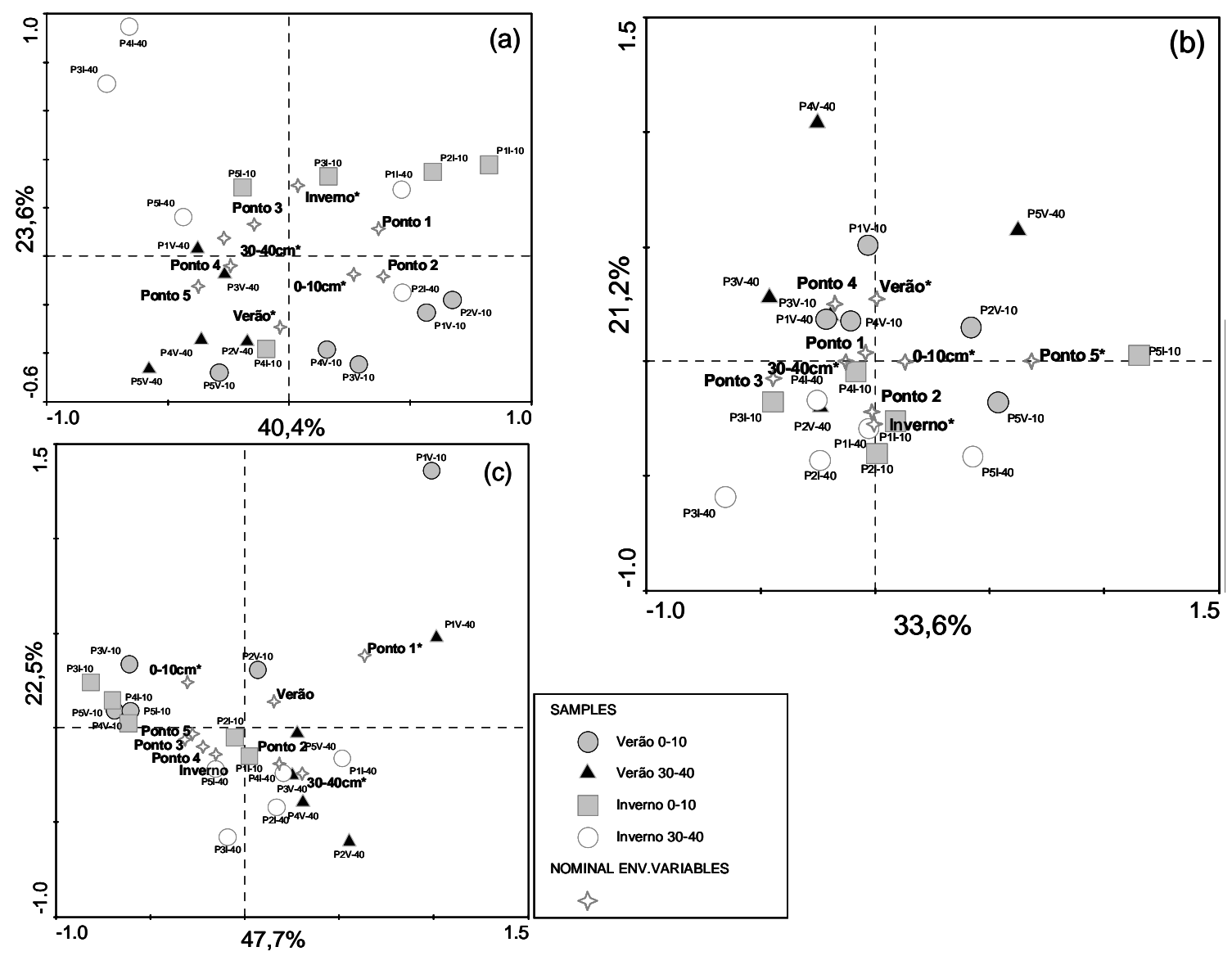

Figura 10. Agrupamento das amostras de sedimento de manguezal pela análise de Redundância (RDA) e relação com fatores ambientais determinantes da comunidade Alfaproteobacteria (a), Betaproteobacteria (b) e Actinobacteria (c) obtido por DGGE. Todas as variáveis ambientais são mostradas, no entanto apenas as marcadas com asterisco foram determinantes na composição das comunidades bacterianas $(p<0.05)$ de acordo com o teste de permutação de Monte Carlo. Os valores indicam a porcentagem da variância dos dados explicada em cada um dos eixos.

A análise dos grupos específicos para Paenibacillus spp. (a) e Pseudomonas spp. (b) mostrou que não houve diferença significativa entre as variáveis estudadas. $O$ gênero Pseudomonas spp. não foi isolado porém a análise de DGGE mostrou que o gênero é diverso em sedimento do manguezal (Figura 11). 

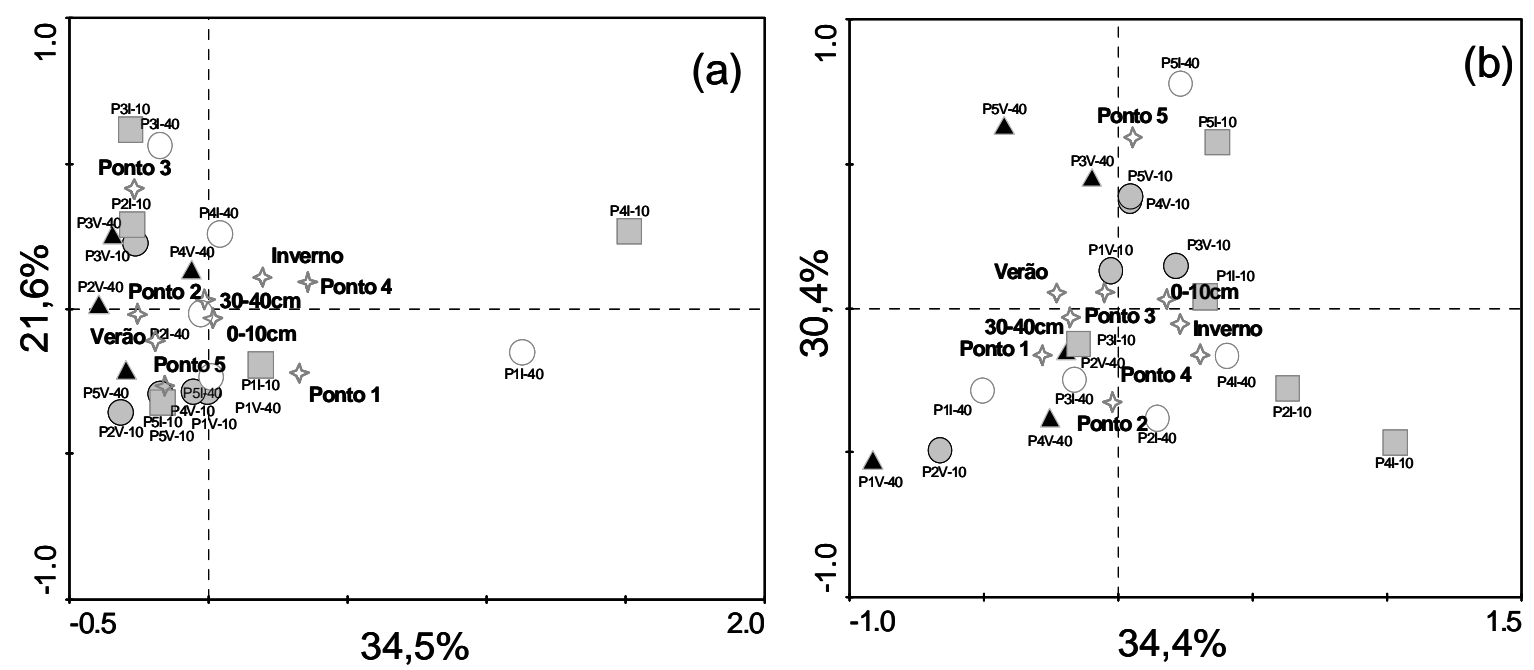

Figura 11. Agrupamento das amostras de sedimento de manguezal pela análise de Redundância (RDA) e relação com fatores ambientais determinantes da população de Paenibacillus spp. e Pseudomonas spp. obtido por DGGE. Todas as variáveis ambientais são mostradas, no entanto apenas as marcadas com asterisco foram determinantes na composição das comunidades bacterianas $(p<0.05)$ de acordo com o teste de permutação de Monte Carlo. Os valores indicam a porcentagem da variância dos dados explicada em cada um dos eixos. 


\section{DISCUSSÃO}

O presente trabalho isolou bactérias de sedimento do manguezal preservado situado na Ilha do Cardoso (Cananéia, SP), permitindo a determinação de grupos bacterianos cultiváveis, bem como avaliar o potencial biotecnológico para a produção de enzimas por estes isolados. Adicionalmente o trabalho visou determinar os principais fatores ambientais que determinam à composição das comunidades bacterianas neste ambiente. Diferentes densidades bacterianas foram encontradas em diferentes estações do ano, enquanto que densidades similares foram observadas em diferentes profundidades. Estes dados sugerem que a capacidade suporte de bactérias não varia ao longo do perfil do sedimento, sendo as alterações devido à profundidade principalmente devidas às diferenças nas estruturas das comunidades. Em relação à sazonalidade, as diferenças observadas podem estar associadas às alterações na disponibilidade de nutrientes, que é amplamente afetada pelo regime de chuva e o comportamento de correntes marítimas que variam ao longo do ano (SILVA 1989; CARMOUZE et al., 1998; CRUMP et al., 2003 e 2004; HENRIQUES et al., 2006; SILVA et al., 2006; KRISHNAN et al., 2007).

Considerando a estrutura destas comunidades avaliadas em diferentes épocas do ano e em diferentes profundidades, inicialmente a separação dos isolados obtidos em ribotipos mostrou a ocorrência de grupos bacterianoso previamente descritos em ambientes marinhos e estuarinos. Foi verificada uma dominância da ordem Vibrionales (ribotipo A), que respondeu às alterações nas características climáticas, pluviométricas e salinas. A resposta deste grupo bacteriano a fatores ambientais foi previamente descrita na literatura (TROUSSELLIER et al., 2002; THOMPSON et al., 2004; SOUZA et al., 2006). O segundo grupo mais freqüentemente isolado das amostras avaliadas foi a ordem Actinomycetales (ribotipo B), que ao contrário de Vibrionales, se manteve constante nos dois isolamentos realizados. Isto evidencia sua estabilidade no ecossistema independente das condições climáticas. Este grupo de bactérias é conhecidamente como colonizador de solos, onde parece responder pouco a alterações ambientais (TAKEUCHI e HATANO, 1998; TIAGO et al., 2004; LIU et al., 2005). Os ribotipos (C, D, E e F) compreendem as bactérias da ordem Bacillales, representados pelos gêneros Bacillus, Staphylococcus, Paenibacillus e Kurthia. FAN et al., (2006) relataram a ocorrência desses gêneros em ambientes estuarinos, enquanto isolados de Staphylococcus foram também encontrados em alta densidade em ecossistemas de manguezais (HOLGUIN e BASHAN, 1996; KATHIRESAN, 2003). Os demais ribotipos compreendem os gêneros Kytococcus, Nesteronkonia e Rothia, que são bactérias pertencentes à ordem Actinomycetales, que foram isoladas em menor quantidade na estação do verão e são relatadas na literatura como presentes em ambientes aquáticos (TIAGO et al., 2004). Em sedimentos marinhos, gêneros como Microbacterium spp. e Vibrio spp. são encontrados em 
função de sua associação a alguns animais marinhos e seus produtos de decomposição (YU et al., 2004). Em estudo realizado no Canadá, de cultura de diversos peixes, moluscos, sedimentos e águas marinhas, foi observado a partir do perfil de bandas de DGGE e biblioteca de 16S DNAr, vários gêneros dentre os quais Microbacterium spp., Kocuria spp., Bacillus spp., Pseudomonas spp. e Vibrio spp. (SCHULZE et al., 2006).

Considerando outros trabalhos onde ambientes similares e técnicas parecidas foram aplicadas, Stevens et al. (2007) estudaram o estuário de Wadden - Alemanha e a partir de isolamentos e técnicas independentes de cultivo, seguida da criação de clones de DNAr 16S, avaliaram a diversidade microbiana e observaram isolados pertencentes aos filos Actinobacteria e Firmicutes, com a presença dos gêneros Microbacterium e Bacillus. Por meio da análise por ARDRA de sedimentos e água da baía de Sagami no Japão, foram observadas 14 linhagens da família Vibrionaceae, as quais foram usadas como padrão de comparação com 129 linhagens isoladas, que foram agrupadas em 6 ribotipos distintos, todos os membros do gênero Vibrio. Isso foi feitos com o uso de cinco enzimas de restrição (TSUKAMOTO et al., 2006). Da mesma forma, sedimentos e águas marinhas da Tunísia, foi isolado Vibrio ficheri após cultivo em ambiente estável por um ano. A análise de restrição com a enzima HaeIII foi eficiente para confirmar que se tratava das mesmas linhagens isoladas (AMEL et al., 2006).

De maneira geral, correlacionando os resultados obtidos no presente estudo com os demais trabalhos da literatura, é possível sugerir a estratificação das comunidades bacterianas presentes em sedimento de manguezais em dois grupos principais, sendo o primeiro constante, estando sempre presente neste ambiente de forma pouco responsiva a alterações ambientais, enquanto que o segundo grupo é extremamente variável, tendo sua população qualitativa e quantitativamente modulada pelas condições do ambiente que podem variar de maneira intensa em diferentes profundidades ou ao longo do ano.

No entanto, para uma afirmação mais precisa de quais frações das comunidades são aptas a responder as alterações do ambiente, outras análises, principalmente incluindo análises independentemende de cultivo são necessárias. O estudo da comunidade de microrganismos de forma independentemente de cultivo, tem sido uma ferramenta importante na descrição da diversidade bacteriana bem como no monitoramento de comunidades microbianas em diversos ambientes.

Por compor um ambiente ainda pouco explorado, os manguezais podem conter uma extensão da diversidade microbiana ainda em grande parte desconhecida, sugerindo haver neste ambiente muitos produtos úteis que podem ser identificados a partir de microorganismos isolados do sedimento deste ambiente. Esta indicação leva à importância da estratégia de cultivo no conhecimento do potencial metabólico destes microrganismos de possível interesse industrial. 
O estudo do perfil enzimático in vitro da microbiota isolada do sedimento do manguezal da Ilha do Cardoso destacou representantes de três diferentes ordens bacterianas como principais produtores enzimáticos neste ambiente: Vibrionales, Actinomycetales e Bacillales, que foram capazes de produzir amilases, proteases, esterases e lipases. Num contexto geral, foi observada uma versatilidade metabólica do grupo Vibrionales, que produziu diversas enzimas, o que pode ser justificado em função das características adaptativas desses microrganismos ao seu habitat natural, ou seja, o ambiente aquático (THOMPSON et al, 2004a, VENUGOPAL e SARAMMA, 2006). Foi descrito que Vibrio fluvialis, isolado de sedimento do manguezal de Cochin - Índia, produz uma protease alcalina extracelular, a qual após purificação em condições químicas e físicas diversas pode ser usada como importante substrato na fabricação de detergente industrial (VENUGOPAL e SARAMMA, 2006). Outros estudos mostram ainda a produção de protease pelos outros grupos bacterianos também encontrados no presente estudo, como visto para Microbacterium sp.. (THYS et al., 2006). Da mesma forma, e GHOSH et al., (2007) observaram que entre a população amostrada 50\% pertenciam aos filos das Actinobacteria e Firmicutes, com $76 \%$ dos isolados apresentando atividade proteolítica. Adicionalmente, LAGEIRO et al., (2007) em estudos com membros do gênero Bacillus demonstraram que este gênero produz enzimas proteolíticas.

Considerando diferentes amostras, obtidas nos pontos ou em profundidades distintas, foi possível observar principalmente o efeito da profundade amostrada, e do ponto 4 na atividade enzimática dos isolados. Inicialmente considerando a profundidade amostrada, a tensão de oxigênio pode ser determinante na atividade destas enzimas e na necessidade de tais atividades como vantagem adaptativa para os isolados destas amostras. As atividades proteásica, amilolítica e esterásica foram maiores neste ambiente. Com base nos dados de disponibilidade de nutrientes em matéria orgância nos pontos e nas profundidades amostradas, é possível verificar que em maiores profundidades ocorre menor disponibilidade de nutriente prontamente disponível, o que exige a degradação de compostos mais complexos que não foram degradados quando presentes na superfície do sedimento.

Primeiramente o ponto 4 mostrou ser a principal fonte de isolados produtores de enzimas proteolíticas, amilolíticas e esterásicas. Neste ponto, estas atividades foram mais freqüentes em isolados obtidos das amostras de maior profundidade $(30-40 \mathrm{~cm})$. A atividade amilolítica do ponto 5 foialta, comparável à encontrada no ponto 4. A única atividade enzimática que não foi maior no ponto 4 foi a atividade lipolítica, que se mostrou mais intensa no ponto 2 e em camadas mais superficiais do sedimento $(0-10 \mathrm{~cm})$.

Diferentes profundidades de solo foram também amostradas no parque Tiergarten em Berlin onde a análise microbiológica mostrou que as contagens de colônias variaram e a análise 
por ARDRA mostrou comunidades bacterianas homogêneas. Neste mesmo trabalho a atividade enzimática esterásica e lipolítica evidenciou a capacidade dos microrganismos em utilizar o substrato nas amostras analisadas (BRAUN et al., 2006).

Técnicas independentes de cultivo têm sido usadas juntamente com análises estatísticas aprimoradas, como forma de dimensionar e aumentar a informação de grupos de organismos em relação às condições ambientais, flutuações sazonais e diferentes aspectos do local estudado (HITZL et al., 1997; FROMIN et al., 2002; XU, 2006; RAMETTE, 2007).

As análises estatísticas multivariadas associadas aos perfis de DGGE com oligonucleotídeos para comunidade total bacteriana e para os grupos de Alfa e Betaproteobacteria e Actinobacteria mostraram uma diferença significativa nas profundidades estudadas. Isso se deve provavelmente à diferentes condições de oxigenação, que parece ser seletiva para a composição das comunidades bacterianas de maneira qualitativa, quantitativa e funcional. Em função do alagamento que ocorre em áreas de manguezais, a taxa de difusão do oxigênio no sedimento sofre uma diminuição de cerca de 10.000 vezes, tornando-se muito inferior à demanda microbiana para oxidação da matéria orgânica. A decomposição passa então a ocorrer por meio de microrganismos anaeróbios, o que acarreta e alterações nas comunidades bacterianas. ALONGI et al., (1998) estudaram três manguezais na península da Malásia, comparando a idade da flora dominada pelo gênero Rhizophora em relação a composição de diferentes profundidades no sedimento constatando que os bosques se mantêm estáveis no teor de matéria orgânica total e as florestas mais jovens sofrem maior impacto quanto às condições aeróbias e anaeróbias do sedimento. Em sedimento do manguezal ao sul da Tailândia a composição de carbono, sulfato, gás carbônico e oxigênio foram avaliados mostrando que o ambiente retém $60 \%$ do carbono total e a mineralização varia de 27 a $40 \%$ sendo importante a presença de microrganismos para a ocorrência do processo (ALONGI et al., 2001). Em sedimentos ao longo de uma faixa na Geogia EUA foi estimada a taxa de reações e respiração anaeróbias junto à mineralização de material orgânico em função do tempo e espaço, concentrações de compostos férricos e sulfatados bem como, foi observado que a vegetação causou perturbação na microbiota do ambiente (KOSTKA et al., 2002).

Em relação às estações do ano, as comunidades se diferenciaram nos DGGEs dos grupos de Alfa-Proteobacteria e Beta-Proteobacteria. As variações de temperatura, salinidade e teores de matéria orgânica podem ter influenciado a comunidade bacteriana no inverno e no verão. No complexo estuarino em Ria de Aveiro ao longo do Canal de Ilhavo a biomassa microbiana variou em relação a demanda de carbono, salinidade, profundidade e sazonalidade (ALMEIDA et al., 2001 e 2002). ALMEIDA et al., (2007) avaliaram quatro estuários em estações diferentes, onde obsservaram que a produtividade bacteriana variou em conseqüência do teor de salinidade e dos 
fatores ambientais. Em contrapartida, a densidade se manteve mais estável no período do inverno com atividade bacteriana superando a do verão. Dessa forma, foi sugerido que devido ao alto índice pluviométrico os nutrientes sejam removidos.

Em relação aos pontos amostrados, foi observada diferença significativa entre o ponto 1 para Actinobacteria e o ponto 5 para Beta Proteobacteria e bactérias totais quando comparado aos outros pontos. Conforme Almeida (2005), o elevado grau de conservação dos manguezais da Ilha do Cardoso, a alta pluviosidade e o aporte de nutrientes provenientes da drenagem de pequenos e inúmeros rios da região contribuem para as diferenças ao longo da transversal estudada.

$\mathrm{Na}$ franja do bosque (ponto 1), onde a influência das marés é constante foi demonstrado que a salinidade consiste em um fator indireto na variabilidade da comunidade bacteriana, pois existem muitos microrganismos adaptados a esse tipo de ambiente. Notoriamente, o ponto 5 apresenta o menor índice salino da transição (COELHO-JR, 2003), o que pode justificar sua relação com a composição da comunidade bacteriana.

Corroborando tais informações, Doering et al. (1995); Niels et al. (1999); Zehr et al. (2002); Obernosterer et al. (2003); Smith et al. (2003) reforçam que em ambiente de estuário, ao longo de um gradiente entre sedimento e águas oceânicas, as comunidades bacterianas variam pela limitação de elementos orgânicos e inorgânicos disponíveis.

Vale ressaltar que nem todos os fatores ambientais que podem atuar determinando a composição das comunidades bacterianas são considerados no presente trabalho. Como exemplo de fator não incorporado às análises a incidência de caranguejos em manguezal, que foi previamente estudada em estações distintas no sul dos Estados Unidos promovendo um aumento e ou diminuição nos teores de matéria orgânica devida a remoção do sedimento ou morte (REINSEL, 2004). O autor observou também que a ausência desses crustáceos pode diminuir em até $40 \%$ a taxa de matéria orgânica.

De maneira conclusiva, o presente trabalho mostra importantes pontos da ecologia bacteriana de sedimentos de manguezais, acessando importantes grupos facilmente disponíveis para exploração biotecnológica, bem como fornece informações de grande valia sobre os principais fatores ambientais que influenciam estas comunidades. 


\section{CONCLUSÕES}

- A comunidade bacteriana cultivável do sedimento de manguezal da Ilha do Cardoso é constituída por 10 ribotipos e 14 gêneros bacterianos, sendo Vibrio o mais frequente;

- O ribotipo A constituído por isolados da ordem Vibrionales apresentou potencial para a produção das enzimas amilase, protease, esterase e lípase;

- A diversidade bacteriana cultivável e não cultivável do sedimento de manguezal é variável de acordo com o ponto amostrado, épocas e profundidade. 


\section{REFERÊNCIAS BIBLIOGRÁFICAS}

ALMEIDA M. A.; CUNHA M. A.; ALCÂNTARA F. Factors influencing bacterial production in a shallow estuarine system. Microbial Ecology, v .42, p. 416-426, 2001.

ALMEIDA M. A.; CUNHA M. A.; ALCÂNTARA F. Seasonal change in the proportion of bacterial and phytoplankton production along a salinity gradient in a shallow estuary. Hydrobiology, v. 475/476: p. 251$262,2002$.

ALMEIDA, R. Ecologia de Manguezais: Dinâmica da Serapilheira e Funcionamento do Ecossistema, Ilha do Cardoso, Cananéia, São Paulo, Brasil. (Tese de Doutorado). Universidade de São Paulo, Instituto Oceanográfico,São Paulo, 182p. 2005.

ALMEIDA M .A.; CUNHA M.A.; DIAS J. M. Bacterial Productivity Distribution During a Rainy Year in an Estuarine System. Microbial Ecology, v. 53, p. 208-220, 2007.

ALONGI, D. M. Bacterial productivity and microbial biomasses tropical mangrove sediments. Microbial Ecology v .15, p .59-79, 1988.

ALONGI D. M.; SEKUMAR A.; TIRENDI F.; DIXON P. The influence of stand age on benthic decomposition and recycling of organic matter in managed mangrove forests of Malaysia. Journal of Experimental Marine Biology and Ecology, v. 225, p. 197-218 1998.

ALONGI D. M.; WATTAYAKORN G.; PIFTZNER J.. TIRENDI F.; ZAGORSKIS I.; BRUNSKILL G.J.; DAVIDSON A.; CLOGH B.F. Organic carbon accumulation and metabolic pathways in sediments of mangrove forests in southern Thailand. Marine Geology, v. 179, p. 85-103, 2001.

AMANN, R. I.; LUDWIG, W.; SCHLEIFER, K. H. Phylogenetic identification and in situ detection of individual microbial cells without cultivation. Microbiological Reviews, v. 59, p.143-169, 1995.

ANDREOTE, F. D.; GULlO, M. J. M.; LIMA, A. O. S.; MACCHERONI, W.; AZEVEDO, J. L.; ARAUJO, W. L. Impact of genetically modified Enterobacter cloacae on indigenous endophytic community of Citrus sinensis seedlings. Journal of Microbiology, v. 42, p. 169-173, 2004.

ANDREOTE F. D.; LACAVA P. T.; GAI C. S.; ARAÚJO W. L.; MACCHERONI, W. JR.; OVERBEEK L. S. V.; ELSAS J. D. V.; AZEVEDO J. L. Model plants for studying the interaction between Methylobacterium mesophilicum and Xylella Fastidiosa. Canadian Journal Microbiology, v. 52, p. 419426, 2006.

ARAÚJO, W. L.; MARCON, J.; MACCHERONI JR.; VAN ELSAS, J. D.; VAN VUURDE, J. W. L.; AZEVEDO, J. L. Diversity of Endophytic Bacterial Population and Interaction with Xylella fastidiosa in Citrus Plants. Applied and Environmental Microbiology, v. 68, p. 4906-4914, 2002.

AZEVEDO, J. L. Biodiversidade Microbiana e Potencial Biotecnológico. In: MELO, I. S.; AZEVEDO, J. L. Ecologia Microbiana. Jaguariúna: Embrapa-CNPMA, 1998. 488p.

BAKONYI T.; DERAKHSHIFAR I.; GRABENSTEINER L.; NOWOTNY N. Development and evaluation of PCR assays for the detection of Paenibacillus larvae in honey samples: comparison with isolation and biochemical characterization. Applied Environmental Microbiology, v. 69, p. 1504-1510, 2003.

BANO, N.; NISA, M. U.; KHAN, N.; SALEEM, M.; HARRISON, P. J.; AHMED, S. I.; AZAM, F. Significance of bacteria in the flux of organic matter in the tidal creeks of the mangrove ecosystem of the Indusriver delta, Pakistan. Marine Ecology Progress Service v. 157, p. 1-12, 1997. 
AMEL B. K. N.; AMINE B.; AMINA B. Survival of Vibrio fluvialis in seawater under starvation conditions, Microbiological Research. 2006. in press

BISWAS H.; MUKHOPADHYAY S. K.; SEN S.; JANA T. K. Spatial and temporal patterns of methane dynamics in the tropical mangrove dominated estuary, NE coast of Bay of Bengal. India Journal of Marine Systems, v. 68, p. 55-64, 2007.

BOUILLON S.; MOENS T.; KOEDAM N.; GUEBAS F. D.; BAEYENS W.; DEHAIRS F. Variability in the origin of carbon substrates for bacterial communities in mangrove sediments. FEMS Microbiology Ecology, v.49, p. 171-179, 2004.

BRAUN B.; BOCKELMANN U.; GROHMANN E.; SZEWZYK U. Polyphasic characterization of the bacterial community in an urban soil profile with in situ and culture-dependent methods. Applied Soil Ecology, v.31, p. 267-279, 2006.

BRIM, H.; HEUER, H.; KRÖGERRECKLENFORT, E.; MERGEAY, M.; SMALLA, K. Characterization of bacterial community of a zinc-polluted soil. Canadian Journal of Microbiology, v. 45, p. 326-338, 1999.

BRITO E. M. S.; GUYONEAUD R.; URRIZA M. G.; PEYRUSE A. R.; VERBAERE , MIRIAM A.; CRAPEZ A.C.; WASSERMAN J. C.; DURAN R. Characterization of hydrocarbonoclastic bacterial communities from mangrove sediments in Guanabara Bay, Brazil. Research in Microbiology, v. 157, p. 752-762, 2006.

CARMOUZE J. P.; GALVÃO S.G.; NISHIARA L.; MESQUITA H. S. L. Modelling chemical changes of tidal waters emerging from a mangrove forest at Cananeia, Brazil Mangroves and Salt Marshes, v. 2, p. 43-49, 1998.

CHANDRASEKARAN, M. Industrial enzymes from marine microorganisms: The Indian scenario. Journal Marine Biotechnology, v. 5, p. 86-89, 1997.

CHECNEBY D.; PHILIPPOT L.; HARTMANN A.; HENAULT C.; GERMON J. C. 16S rDNA analysis for characterization of denitrifying bacteria isolated from three agricultural soils. FEMS Microbiology Ecology, v. 34: p. 121-128, 2000.

COELHO-JR, C. 2003. Ecologia de Manguezais: Zonação e dinâmica dos bosques de mangue em gradientes ambientais (Cananéia, São Paulo). Tese de Doutorado, Universidade de São Paulo, Instituto Oceanográfico, São Paulo, 165p.

COOKSON W.R.; OSMAN M.; MARSCHNER P.; ABAYE D.A.; CLARK I.; MURPHY D.V.; STOCKDALE E.A.; WATSON C.A. Controls on soil nitrogen cycling and microbial community composition across land use and incubation temperature. Soil Biology \& Biochemistry, v. 39, p. 744-756, 2007.

CRUMP B. C., KLING G. W.; BAHR M.; AND J. E. HOBBIE. Bacterioplankton community shifts in an arctic lake correlate with seasonal changes in organic matter source. Applied and Environmental Microbiology, v. 69, p. 2253-2268, 2003.

CRUMP, B. C.; HOPKINSON, C. S.; SOGIN, M. L.; HOBBIE, J. E. Microbial biogeography along an estuarine salinity gradient: combined influences of bacterial growth and residence time. Applied and Environmental Microbiology, v. 70, p. 1494-1505, 2004.

DA SILVA K. R. A.; SALLES J. F.; SELDIN L.; VAN ELSAS J. D. Application of a novel Paenibacillusspecific PCR-DGGE method and sequence analysis to assess the diversity of Paenibacillus spp. in the maize rhizosphere. Journal of Microbiological Methods, v. 54, p. 213-231, 2003. 
DINERSTEIN, E.; OLSON, D. M.; GRAHAM, D.; WEBSTER, A.; PRIMM. S.; BOOKBINDER, M.; LEDEC, G. A conservation assessment of the terrestrial ecoregions of Latin America and the Caribbean. World Wildlife Foundation, v. 44 p. 321-334, 1995.

DOERING P. H.; OVIATT B. L.; NOWICKI E. G.; KLOS L. W. Reed phosphorus and nitrogen limitation of primary production in a simulated estuarine gradient. Marine Ecology Progress Series, v. 124, p. 271287, 1995.

FAN L.F.; SHIEH W. Y.; WU W. F., CHEN C. P.; Distribution of nitrogenous nutrients and denitrifiers strains in estuarine sediment profiles of the Tanshui River, northern Taiwan. Estuarine, Coastal and Shelf Science, v.69, p. 543-553, 2006.

FANTROUSSI, S.; VERSCHUERE, L.; VERSTRAETE, W.; TOP, E. M.; Effect of phenylurea herbicides on soil microbial communities estimated by analysis of $16 \mathrm{~S}$ rRNA gene fingerprints and community-level physiological profiles. Applied and Environmental Microbiology, v. 65, p. 982-988, 1999.

FELLER I. C.; SITNIK M. Mangrove ecology. Smithsonian Institution, p.1-129, 1996.

FROMIN N.; HAMELIN J.; TARNAWSKI S.; ROESTI D.; JOURDAIN-MISEREZ K.; FORESTIER N.; TEYSSIER-CUVELLE S.; GILLET,; ROSSI M. A. P. Statistical analysis of denaturing gel electrophoresis (DGE) fingerprinting patterns. Environmental Microbiology, v. 11, p. 634-643, 2002.

GARBEVA, P.; VAN OVERBEEK, L. S.; VAN VUURDE, J. W. L.; VAN ELSAS J. D. Analysis of endophytic bacterial communities of potato by plating and denaturing gradient gel electrophoresis (DGGE) of 16S rDNA based PCR fragments. Microbial Ecology, v. 41, p. 369-383, 2001.

GARBEVA, P.; VAN VEEN, J. A.; VAN ELSAS, J. D. Assessment of the diversity, and antagonism towards Rhizoctonia solani AG3, of Pseudomonas species in soil from different agricultural regimes. FEMS Microbiology Ecology, v. 47, p. 51-64, 2004.

GHOSH1 A.; MAITY B.; CHAKRABARTI K.; CHATTOPADHYAY D. Bacterial diversity of east calcutta wet land area: possible identification of potential bacterial population for different biotechnological uses. Microbial Ecology, v. 54, p. 452-459, 2007.

GOMES NCM, HEUER H, SCHONFELD J, COSTA R, MENDONCA-HAGLER L, SMALLA K Bacterial diversity of the rhizosphere of maize (Zea mays) grown in tropical soil studied by temperature gradient gel electrophoresis. Plant and Soil, v. 232, p. 167-180, 2001.

GUCHT K. V. D.; VANDEKERCKHOVE T.; VLOEMANS N.; COUSIN S.; MUYLAERT K.; SABBE K.; GILLIS M.; DECLERK S.; MEESTER L.; VYVERMAN W. Characterization of bacterial communities in four freshwater lakes differing in nutrient load and food web structure. FEMS Microbiology Ecology, v. 53, p. 205-220, 2005.

GURTNER C. S.; PINAR G.; LUBITZ W.; ROLLEKE S. An advanced molecular strategy to identify bacterial communities on art objects. Journal of Microbiological Methods, v. 45, p. 77-87, 2001.

GUTHRIE J.N.; MORIARTY D.J.W.; BLACKALL L.L. DNA extraction from coral reef sediment bacteria for the polymerase chain reaction. Journal of Microbiological Methods, v. 43, p. 73-80, 2000.

HANKIN L. ANAGNOSTAKIS, S. L. The use of solid media for detection of enzyme production by fungi. Mycologia, v. 67, p. 597-607, 1975.

HAWKINS R. J.; PURDY K. J. Genotypic distribution of an indigenous model microorganism along an estuarine gradient. FEMS Microbiology Ecology, v.62, p. 187-194, 2007. 
HENCKEL T.; FRIEDRICH M.; CONRAD R.; Molecular analyses of the methane-oxidizing microbial community in rice field soil by targeting the genes of the $16 \mathrm{~S}$ rRNA, particulate methane monooxygenase, and methanol dehydrogenase. Applied and Environmental Microbiology, v. 66, p. 1980-1990, 1999.

HENRIQUES I. S.; ALVES A.; TACÃO M.; ALMEIDA A.; CUNHA, A.; CORREIA, A. Seasonal and spatial variability of free-living bacterial community composition along an estuarine gradient (Ria de Aveiro, Portugal). Estuarine Coastal and Shelf Science, v. 68, p. 139-148, 2006.

HENTSCHEL U.; USHER K. M.; TAYLOR M. W. Marine sponges as microbial fermenters. FEMS Microbiology Ecology, v. 55, p. 167-177, 2006.

HEUER H.; KRSEK M.; BAKER P.; SMALLA K.; WELLINGTON E.M.H. Analysis of actinomycete communities by specific amplification of genes encoding $16 \mathrm{~S}$ rRNA and gel-electrophoretic separation in denaturing gradients. Applied and Environmental Microbiology, Washington, v. 63, p. 3233-3241, 1997.

HEUER, H.; SMALLA, K. Application of denaturing gradient gel electrophoresis (DGGE) and temperature gradient gel electrophoresis (TGGE) for studying soil microbial communities. In: ELSAS, J.D. van; TREVORS, J.T.; WELLINGTON, E.M.H. (Ed.). Modern Soil Microbiology, p. 353-373, 1997.

HEYNDRICKX M.; VAUTERIN L.; VANDAMME P.; KERSTERS K.; VOS P. D. Applicability of combined amplified ribosomal DNA restriction analysis (ARDRA) patterns in bacterial phylogeny and taxonomy. Journal of Microbiological Methods, v. 26, p. 247-259, 1996.

HITZL W.; HENRICH M.; KESSEL M.; INSAM H. Application of multivariate analysis of variance and related techniques in soil studies with substrate utilization tests. Journal of Microbiological Methods, v. 30, p. 81-89, 1997.

HOLGUIN G.; BASHAN Y.; nitrogen-fixation by azospirillum brasilense cd is promoted when co-cultured with a mangrove rhizosphere bacterium (staphylococcus sp.). Soil Biology \& Biochemistry. v. 28, p. 1651-1660, 1996.

HOLGUIN G.; ZAMORANO P. G.; BASHAN L. E. D.; MENDOZA R.; AMADOR E.; BASHAN Y. Mangrove health in an arid environment encroached by urban development - a case study. Science of the Total Environment, v. 363, p. 260-274, 2006.

JAEGER K. E.; SCHNEIDINGER, B., ROSENAU F.; WERNER M.; LANG D.; DIJKSTRA B. W.; SCHIMOSSEK K.; ZONTA A.; REETZ M. T. Bacterial lipases for Biotechnological applications. Journal of Molecular Catalysis B: Enzymatic, v. 3, p. 3-12, 1997.

JAEGER K. E.; EGGERT T. Lipases for biotechnology. Current Opinion in Biotechnology, v. 13, p. 390-3972002.

JENSEN P. R.; GONTANG E.; MAFNAS C.; MINCER T. J.; FENICAL W. Culturable marine actinomycete diversity from tropical Pacific Ocean sediments. Environmental Microbiology, v. 7, p. $1039-1048,2005$.

JOURNETT T. D.; ARNOLD W. A.; LAPARA T. M. The characterization and quantification of methanotrophic bacterial populations in constructed wetland sediments using PCR targeting 16S rRNA gene fragments. Applied Soil Ecology, v. 35, p. 648-659, 2007.

JUCK D.; CHARLES T.; WHYTE L. G.; GREER C. W. Polyphasic microbial community analysis of petroleum hydrocarbon-contaminated soils from two northern Canadian communities. FEMS Microbiology Ecology, v. 33, p. 241-249, 2000.

KALA R. R.; CHANDRIKA V. Effect of different media for isolation, growth and maintenance of Actinomycetes from mangrove sediments. Indian Journal of Marine Sciences, v. 22, p. 297-299, 1993. 
KATHIRESAN K.; BINGHAM B.L. Biology of Mangroves and Mangrove Ecosystems Advances in Marine Biology, v. 40: p. 81-251, 2001.

KATHIRESAN K.; SELVAM M. Evaluation of beneficial bacteria from mangrove soil. Botanica Marina, v. 49 , p. 86-88, 2006.

KENNEDY N.; BRODIE E.; CONNOLLY J.; CLIPSON N. Impact of lime, nitrogen and plant species on bacterial community structure in grassland microcosms. Environmental Microbiology, v. 6, p. 1070-1080, 2004.

KOIZUMI, Y.; KELLY, J. J.; NAKAGAWA, T.; URAKAWA, T.; EL-FANTROUSSI, S.; ALMUZAINI, S.; FUKUI, M. URUSHIGAWA, Y.; STAHL, D. A. Parallel characterization of anaerobic toluene and ethylbenzene degrading microbial consortia by PCR denaturing gradient gel electrophoresis, RNA-DNA membrane hybridisation, and DNA microarray technology. Applied and Environmental Microbiology, v. 68, p. 3215-3225, 2002.

KOSTKA J. E.; ROYCHOUDHURY A.; CAPPELLEN P. V. Rates and controls of anaerobic microbial respiration across spatial and temporal gradients in saltmarsh sediments. Biogeochemistry, v. 60, p. 49-76, 2002.

KRISHNAN K.P.; FERNANDES S. O.; CHANDAN G. S.; BHARATHI P. A. L. Bacterial contribution to mitigation of iron and manganese in mangrove sediments. Marine Pollution Bulletin, v. 54, p. 1427-1433, 2007.

LACAVA, P. T.; LI, W. B.; ARAUJO, W. L.; AZEVEDO, J. L.; HARTUNG, J. S. Rapid, specific and quantitative assays for the detection of the endophytic bacterium Methylobacterium mesophilicum in plants. Journal of Microbiological Methods, v. 65, p. 535-541, 2006.

LACAVA P. T.; PARKER J.; ANDREOTE F. D.; DINI-ANDREOTE F., RAMIREZ , J. L.; MILLER T. A. Analysis of the bacterial community in glassy-winged sharpshooter heads. Entomological Research, v. 37, p. 261-266, 2007.

LAGEIRO M. M.; MOURA M. J.; REIS A.; FERREIRA M. J. C. Microbial proteases application in leather industry. Journal of Biotechnology v. 131, p. 211-241, 2007.

LALUMERA G. M.; CALAMARI D.; GALLI P.; CASTIGLIONI S.; CROSA G.; FANELLI R. Preliminary investigation on the environmental occurrence and effects of antibiotics used in aquaculture in Italy. Chemosphere, v. 54, p. 661-668, 2004.

LE T. X.; MUNEKAGE Y.; KATO S. Antibiotic resistance in bacteria from shrimp farming in mangrove areas. Science of the Total Environment, v. 349, p. 95-105, 2005.

LI Z. Y.; HE L. M.; WU J.; JIANG Q. Bacterial community diversity associated with four marine sponges from the South China Sea based on 16S rDNA-DGGE fingerprinting. Journal of Experimental Marine Biology and Ecology, v. 329, p. 75-85, 2006.

LIANG J. B.; CHEN Y. Q.; LAN C. Y.; TAM N. F. Y.; ZAN Q. J.; HUANG L. N. Recovery of novel bacterial diversity from mangrove sediment. Marine Biology, v. 150, p. 739-747, 2007.

LIAO P.C.; HUANG B. H.; HUANG S. Microbial Community Composition of the Danshui River Estuary of Northern Taiwan and the Practicality of the Phylogenetic Method in Microbial Barcoding. Microbial Ecology, v. 54, p. 497-507, 2007.

LINDSTRÖM E. S.; BERGSTRÖM A. K. Community composition of bacterioplankton and cell transport in lakes in two different drainage areas. Aquatic Sciences, v. 67, p. 210-219, 2005. 
LIU, J.; NAKAYAMA, T., HEMMI H., ASANO, Y., TSURUOKA, N., SHIMOMURA, K., NISHIJIMA, M.; NISHINO, T. Microbacterium natoriense sp. nov., a novel D-aminoacylase-producing bacterium isolated from soil in Natori, Japan. International Journal of Systematic and Evolutionary Microbiology, v. 55, p.661-665, 2005.

LOVELOCK J. M. The ages of Gaia. Oxford University Press, Oxford, 1988.

MCKINLEY V. L.; PEACOCK A. D.; WHITE D.C. Microbial community PLFA and PHB responses to ecosystem restoration in tallgrass prairie soils. Soil Biology \& Biochemistry, v. 37, p. 1946-1958, 2005.

MENEZES, G. V.; SHAEFFER-NOVELLI, Y.; Produção e decomposição em bosques de mangue na Ilha do Cardoso, Cananéia, SP. Resumos, v. 1, p. 349-350, 1994.

MICHAUD L.; CELLO F. DI; BRILLI M.; FANI R.; GIUDICE A. LO,; BRUNI V. Biodiversity of cultivable psychrotrophic marine bacteria isolated from Terra Nova Bay (Ross Sea, Antarctica). FEMS Microbiology Letters, v. 230, p. 63-71, 2004.

MUYZER, G.; DE WAAL, E.C.; UITTERLINDEN, A.G.; Profiling of complex microbial populations by denaturing gradient gel electrophoresis analysis of polymerase chain reaction-amplified genes coding for 16S rRNA. Applied and Environmental Microbiology, v. 59, p. 695-700, 1993.

NASCIMENTO, W. C. A.; MARTINS, M. L. L.; Production and properties of an extracellular protease from thermophilic Bacillus sp. Brazilian Journal of Microbiology. v. 35, p. 91-96, 2004.

NIELS G.; .JOSRGENSEN L.; NIELS R. B.; COFFIN R.; MATTHEW P. O. Relations between bacterial nitrogen metabolism and growth efficiency in an estuarine and an open-water ecosystem. Aquatic Microbial Ecology, v.18, p .247-261, 1999.

NIEMI R. M.; HEISKANEN I.; WALLENIUS K.; LINDSTROM K. Extraction and purification of DNA in rhizosphere soil samples for PCR-DGGE analysis of bacterial consortia. Journal of Microbiological Methods, v. 45, p. 155-165, 2001.

OBERNOSTERER I.;. KAWASAKI N.; BENNER R. P-limitation of respiration in the sargasso sea and uncoupling of bacteria from P-regeneration in size-fractionation experiments Aquatic Microbial Ecology, v. 32, p. 229-237, 2003.

OVERMANN J.; COOLEN M. J. L.; TUSCHAK C. Specific detection of different phylogenetic groups of chemocline bacteria based on PCR and denaturing gradient gel electrophoresis of 16S rRNA gene fragments. Archives Microbiology, v. 172, p. 83-94, 1999.

PEIXOTO R.S.; COUTINHO H.L.C.; MADARI B.; MACHADO P. L. O. A.; RUMJANEK N. G.; VAN ELSAS J. D.; SELDIN L.; ROSADO A.S. Soil aggregation and bacterial community structure as affected by tillage and cover cropping in the Brazilian Cerrados. Soil \& Tillage Research, v. 90, p. 16-28, .2006.

RAMETTE A. Multivariate analyses in microbial ecology. FEMS Microbiology Ecology, v. 62, p. 142$160,2007$.

RAMETTE A.; TIEDJE J. M. Multiscale responses of microbial life to spatial distance and environmental heterogeneity in a patchy ecosystem. Proceedings of the National Academy of Sciences of the United States of America, v. 104, p. 2761-2766, 2007.

RAMSING N.B.; FOSSING H.; FERDELMAN T.G., ANDERSON, F.; THAMDRUP B. Distribution of bacterial populations in a stratified fjord (Mariager Fjord, Denmark) quantified by in situ hybridization and related to chemical gradients in the water column. Applied Environmental Microbiology, v. 62, p. 13911404, 1996. 
REBER H. H. Simultaneous estimates of the diversity and the degradative capability of heavy-metalaffected soil bacterial communities. Biology and Fertility of Soils, v. 13, p.181-186, 1992.

REINSEL K.A.; Impact of fiddler crab foraging and tidal inundation on an intertidal sandflat: seasondependent effects in one tidal cycle. Journal of Experimental Marine Biology and Ecology, v. 313, p.1$17,2004$.

SAMBROOK, L.; FRITSCH.; MANIATIS, T. Molecular cloning - A Laboratory manual. New York: Cold Spring Harbor Laboratory. 1989.

SCHAEFFER-NOVELLI, Y. Manguezal: ecossistema entre a terra e o mar. São Paulo:USP, Instituto Oceanográfico. p. 64, 1995.

SCHULZE A. D.; ALABI A. O.; SHELDRAKE A. R. T.; MILLER K. M. Bacterial diversity in a marine hatchery: Balance between pathogenic and potentially probiotic bacterial strains. Aquaculture, v. 256, p. 50-73, 2006

SENGUPTA, A,; CHAUDHURI, S. Halotolerant Rhizobium strains from mangrove swamps of the Ganges River Delta. Indian Journal Microbiology, v. 30, p. 483-484, 1990.

SENGUPTA, A.; CHAUDHURI, S. Ecology of heterotrophic dinitrogen fixation in the rhizosphere of mangrove plant community at the Ganges river estuary in India. Oecologia. v. 87, p. 560-564, 1991.

SEYLER T. H.; JAEGER B.; GEIS W. B.; HELLER K. J. Molecular identification and differentiation of Brevibacterium species and strains. Systematic and Applied Microbiology, v. 30, p. 50-57, 2007.

SHARMA, R.; CHISTI, Y.; BANERJEE, U. C. Production, purification, characterization and applications of lipases. Biotechnology Advances. v.19, p.627-662, 2001.

SHOME R.; SHOME B.R.; MANDAL A.B.; BANDOPADHYAY A.K. Bacterial flora in mangroves of Andaman. Part 1: Isolation, identification and antibiogram studies. Indian Journal of Marine Sciences, v. 24, p. 97-98, 1995.

SIERRA, G. A. A simple method for the detection of lypolytic activity of microorganisms and some observations on the influence of the contact between cells and fatty substracts. Antonine van Leeuwenhoeck. v. 28, p. 15-22, 1957.

SILVA C. A. R.; SMITH B. D.; RAINBOW P. S. Comparative biomonitors of coastal trace metal contamination in tropical South America (N. Brazil). Marine Environmental Research, v. 61, p. 439455, 2006.

SILVA J. F. Dados climatológicos de Cananéia e Ubatuba (Estado de São Paulo). Boletim climatológico Instituto Oceanográfico. São Paulo, v. 6, p.1-21, 1989.

SINGH B. K.; MUNRO S.; REID E.; ORD B.; POTTS J. M.; PATERSON E.; MILLARD P. Investigating microbial community structure in soils by physiological, biochemical and molecular fingerprinting methods. European Journal of Soil Science, v. 57, p. 72-82, 2006.

SIVARAMAKRISHNAN，S.; GANGADHARAN，D.; NAMPOOTHIRI，K. M.; SOCCOL，C. R.; PANDEY, A. a-Amylases from Microbial Sources - An Overview on Recent Developments. Food Technology Biotechnology, v. 44, p.173-184, 2006.

SJÕLINGA S.; MOHAMMED S. M.; LYIMOC T. J.; KYARUZIB J. J. Benthic bacterial diversity and nutrient processes in mangroves: impact of deforestation Estuarine, Coastal and Shelf Science, v. 63, p. 397-406, 2005. 
SMALLA K.; SICHLER M. O.; MILLING A.; HEUER H.; BAUMGARTE S.; BECKER R.; NEUBER G.; KROPF S.; ULRICH A.; TEBBE C. C. Bacterial diversity of soils assessed by DGGE, T-RFLP and SSCP fingerprints of PCR-amplified 16S rRNA gene fragments: Do the different methods provide similar results? Journal of Microbiological Methods, 2007.In press.

SMIBERT R. M.; KRIEG N. R. Phenotypic characterization. In: Gerhardt, P.; Murray, R. G. E.; Wood, W. A. and Krieg, N. R. (Eds.). Methods for general and molecular bacteriology, v. 33, p. 607-654, 1994.

SMIT E.; LEEFANG P.; WERNARS K. Detection of shifts in microbial community structure and diversity in soil caused by copper contamination using amplifed ribosomal DNA restriction analysis. FEMS Microbiology Ecology, v. 23, p. 249-261, 1997.

SMITH E. M.; KEMP W. M. Planktonic and bacterial respiration along an estuarine gradient: responses to carbon and nutrient enrichment. Aquatic Microbial Ecology, v. 30, p. 251-261, 2003.

SOUSA, O. V, MACRAE, A.; MENEZES, F. G. R.; GOMES, N. C. M.; VIEIRA R. H. S. F.; MENDONÇA-HAGLER, L. C. S. The impact of shrimp farming effluent on bacterial communities in mangrove waters, Ceara', Brazil. Marine Pollution Bulletin v. 52, p. 1725-1734, 2006.

STEEL R. G. D.; TORRIE, J. H. Principles and procedures of statistics: A biometrical approach.v. 55, p. 633,1980 .

STEVENS H.; BRINKHOFF T.; RINK B.; VOLLMERS J.; SIMON M. Diversity and abundance of Gram positive bacteria in a tidal flat ecosystem. Environmental Microbiology, v. 9, p. 1810-1822, 2007.

STOLZ J. F.; BOTKIN D. B.; DASTOOR M. N. The integral biosphere. In Rambler, M.B.; Margulis, L. \& Fester, R. (eds). Global Ecology. Academic Press, p. 31-49, 1989.

TAKEUCHI, M.; HATANO K. Proposal of six new species in the genus Microbacterium and transfer of Flavobacterium marinotypicum ZoBell and Upham to the genus Microbacterium as Microbacterium maritypicum comb. International Journal of Systematic Bacteriology, v. 48, p. 973-982, 1998.

TER BRAAK C. J. F.; ŠMILAUER P. CANOCO Manual and Cano Draw for Windows User's Guide: Software for Canonical Community Ordination (version 4.5), 500f, 2002.

TESKE A.; WAWER C.; MUYZER G.; RAMSING N.B.Distribution of sulfate-reducing bacteria in a stratified fjord (Mariager Fjord, Denmark) as evaluated by most-probable-number counts and denaturing gradient gel electrophoresis of PCR-amplified ribosomal DNA fragments. Applied Environmental Microbiology, v. 62, p. 1405-1415, 1996.

THOMPSON, F. L.; IIDA, T.; SWINGS, J. Biodiversity of Vibrios Microbiology and Molecular Biology Reviews, v. 9, p. 403-431, 2004a

THOMPSON, J. R.; RANDA, M. A.; MARCELINO, L. A.; MITCHELl, A. T.; LIM, E.; POLZ M. F. Diversity and Dynamics of a North Atlantic Coastal Vibrio Community Applied And Environmental Microbiology, v. 6, p. 4103-4110, 2004.

THYS R. C. S.; GUZZON S. O.; OLIVERA F. C.; BRANDELLI A. Optimization of protease production by Microbacterium sp. in feather meal using response surface methodology. Process Biochemistry, v. 41, p. $67-73,2006$.

TIAGO I.; CHUNG A. P.; VERISSIMO A. Bacterial Diversity in a Nonsaline Alkaline Environment: Heterotrophic Aerobic Populations. Applied and environmental microbiology, v. 12, p. 7378-7387, 2004.

TORSVIK V.; DAAE F. L.; SANDAA R. A.; OVREAS, L. Novel techniques for analyzing microbial diversity in natural and perturbed environments. Journal of Biotechnology, v. 64, p. 53-62, 1998. 
TROUSSELLIER M.; SCHAFER H.; BATAILLER N.; BERNARD L.; COURTIES C.; LEBARON P.; MUYZER G.; SERVAIS P.; VIVES-REGO J. Bacterial activity and genetic richness along an estuarine gradient (Rhone River plume, France). Aquatic Microbial Ecology v. 28: p. 13-24, 2002.

TRÜPER H.G. Prokaryotes: an overview with respect to biodiversity and environmental importance. Biodiversity and Conservation, v.1, p. 227-36, 1992.

TSUKAMOTO K. K.; YAO K.; KAMIYA A.; YOSHIZAWA S.; UCHIYAMA N.; KOGURE K.; WADA M. Rapid identification of marine bioluminescent bacteria by amplified 16S ribosomal RNA gene restriction analysis. FEMS Microbiology Letters, v. 256, p. 298-303, 2006.

VAN ELSAS J. D. ; DUARTE G.F.; ROSADO A.S.; SMALLA K. Microbiological and molecular biological methods for monitoring microbial inoculants and their effects in the soil environment. Journal of Microbiological Methods, v. 32, p. 133-154, 1998.

VENUGOPAL M.; SARAMMA A. V. Characterization of alkaline protease from Vibrio fluvialis strain VM10 isolated from a mangrove sediment sample and its application as a laundry detergent additive. Process Biochemistry. v. 41, p. 1239-1243, 2006.

VIEIRA J. D. G. Purificação e caracterização de uma alfa-amilase de Streptomyces sp. PhD. Thesis, Universidade de São Paulo, Brasil. 1999.

VIKINESWARY S.; NADARAJ P.; WONG W.H.; BALABASKARAN S. Actinomycetes from a tropical mangrove ecosystem anti-fungal activity of selected strains. Asia Pacific Journal of Molecular Biology and Biotechnology, v. 5, p. 81-86, 1997.

VITI C.; GIOVANNETTI L. Characterization of cultivable heterotrophic bacterial communities in $\mathrm{Cr}$ polluted and unpolluted soils using Biolog and ARDRA approaches. Applied Soil Ecology, v. 28, p. 101$112,2005$.

WEBSTER G.; NEWBERRY C. J.; FRY J. C.; WEIGHTMAN A. J. Assessment of bacterial community structure in the deep sub-seafloor biosphere by $16 \mathrm{~S}$ rDNA-based techniques: a cautionary tale. Journal of Microbiological Methods, v. 55, p. 155-164, 2003.

WEHRL M.; STEINERT M.; HENTSCHEL U. Bacterial Uptake by the Marine Sponge Aplysina aerophoba. Microbial Ecology, v. 53, p. 355-365, 2007.

WhITMAN W. B.; COLEMAN D. C.; WIEBE W. J. Prokaryotes: the unseen majority. Proceedings of the National Academy of Sciences of the U.S.A., v. 95, p. 6578-6583, 1998.

WU X.Y.; WALKER M. J.; HORNITZKY M.; CHIN J. Development of a group-specific PCR combined with ARDRA for the identification of Bacillus species of environmental significance. Journal of Microbiological Methods, v. 64, p. 107-119, 2006.

XU J. Microbial ecology in the age of genomics and metagenomics: concepts, tools, and recent advances. Molecular Ecology, v. 15, p. 1713-1731, 2006.

YANG C. H.; CROWLEY D. E. Rhizosphere microbial community structure in relation to root location and plant iron nutritional status. Applied and Environmental Microbiology, v. 66, p. 345-351, 2000.

YU C .F.; YU P. H. F.; CHAN P. L.; YAN Q.; WONG P. K. Two novel species of tetrodotoxin-producing bacteria isolated from toxic marine puffer fishes. Toxicon, v. 44, p. 641-647, 2004.

ZEHR J. P.; WARD B. B. Nitrogen cycling in the ocean: new perspectives on processes and paradigms. Applied and Environmental Microbiology, v. 68, p.1015-1024, 2002. 
ZHOU H. W.; GUO C. L.; WONG1 Y. S.; TAM N. F. Y. Genetic diversity of dioxygenase genes in polycyclic aromatic hydrocarbon-degrading bacteria isolated from mangrove sediments. FEMS Microbiology Letters, v. 262, p. 148-157, 2006. 